Article

\title{
Community-Based Tourism in Ecuador: Community Ventures of the Provincial and Cantonal Networks
}

\author{
Claudia Patricia Maldonado-Erazo 1(D, María de la Cruz del Río-Rama ${ }^{2, *(1)}$, \\ Patricio Noboa-Viñan ${ }^{1}\left[\right.$ and José Álvarez-García ${ }^{3}$ (1) \\ 1 Facultad de Recursos Naturales, Escuela de Ecoturismo de la Superior Politécnica de Chimborazo-ESPOCH, \\ Riobamba 060155, Ecuador; claudia.maldonado@espoch.edu.ec (C.P.M.-E.); gnoboa@espoch.edu.ec (P.N.-V.) \\ 2 Business Management and Marketing Department, Faculty of Business Sciences and Tourism, \\ University of Vigo, 32004 Ourense, Spain \\ 3 Financial Economy and Accounting Department, Faculty of Business, Finance and Tourism, \\ University of Extremadura, 10071 Cáceres, Spain; pepealvarez@unex.es \\ * Correspondence: delrio@uvigo.es; Tel.: +34-988368727
}

Received: 14 June 2020; Accepted: 31 July 2020; Published: 3 August 2020

\begin{abstract}
The aim of this work is to identify community the initiatives anchored to community-based tourism (CBT) in Ecuador with the aim of providing an overview of the current reality of community tourism in the country, in addition to publicizing the product lines under development within community initiatives. The methodology used is a descriptive analysis based on the review of secondary sources, which reflect the reality of the different tourism initiatives related to the Plurinational Federation of Community Tourism of Ecuador (FEPTCE) at the level of continental Ecuador. FEPTCE groups indigenous, Afro-Ecuadorian, Montubian and mestizo communities, who depend on their territory and have identified tourism as a mechanism to continue living with dignity within these territories, due to the option of economic diversification that is generated. Within the communities that belong to the FEPTCE, living with dignity implies achieving a good quality of life, which is not based on satisfying a series of basic needs, but implies going further, achieving the idea of "Good Living", that is to say, reaching an appreciation of well-being, based on the conception of the full set of what culture is, in order to generate comprehensive sustainability of its spaces. Among the main results, the distribution and coverage that the FEPTCE has within continental Ecuador regarding community tourism is shown and analyzed. As a formal network of community-based tourism, it is made up of five networks at the regional level and nine at the provincial or cantonal level, which are analyzed in this study. The consolidation of the initiatives launched has been difficult with only 83 of the initial 121 being active and only 18 registered as community tourist centers. This case study shows that in Ecuador the network approach as the first step in the development of the CBT worked. Therefore, the development of the CBT must be approached from a network approach in which indigenous peoples (indigenous, mestizo, Afro-descendant, etc.) participate, administrations, the private sector, civil society, NGOs and tourist destinations, to which they must to join academic institutions by contributing solid data obtained through research that helps tourism development.
\end{abstract}

Keywords: community tourism; communities; cultures; community tourism of Ecuador (FEPTCE); Ecuador

\section{Introduction}

Community-based tourism (CBT) is currently being developed in different parts of the world (Asia, Africa and Latin America) as an alternative to traditional tourism [1] and as a tool for the sustainable development of underdeveloped destinations [2]. This type of tourism according to Chernela [3] 
provides an important source of economic resources to local communities, allowing them to improve their quality of life, minimize the impacts on environmental and cultural resources and protect their values and forms of knowledge and obtaining by the visitor of a quality experience. CBT is protected and empowered by different international organizations such as World Wide Fund for Nature and World Tourism Organization [4,5] and following this same line the World Tourism Organization [6] proposes several objectives to be achieved with community tourism: the socioeconomic development of the local community, the conservation of natural and cultural resources and the quality perceived by the tourist demand [7] (p. 277).

The Word Wide Fund for Nature defines CBT as that type of tourism "where the local community has substantial control over-and involvement in-its development and management, and a greater proportion of the benefits remain within the community. WWF accepted that the concept of community depends on local "social and institutional structures" and accepted that it must also embrace individual initiatives within the community" [4] (p.2). Therefore, community tourism is a model of tourism characterized by the fact that rural communities (indigenous or mestizo) are responsible for at least part of its control and also receive part of its economic benefits [8]. community-based tourism is presented as a cultural meeting space, which allows for consensual participation, both of visitors and community members. It is also presented as an opportunity to boost the economy by expanding income generation options through the use of natural and cultural resources in the area [9] and as an alternative to traditional and mass tourism.

Community tourism is closely linked to sustainable development; economic sustainability that improves the sociocultural well-being of target communities and ecological or environmental communities by protecting the natural and built environment [10-12]. The World Commission on Environment and Development (WCED) defined sustainable development as development that "meets the needs of the present without compromising the ability of future generations to meet their own needs" [13] (p. 43). Therefore, community tourism refers to a form of tourism that seeks to satisfy the current needs of tourists, to the tourism industry and to local communities, without compromising the ability to meet the needs of future generations.

For the development of the CBT there are several studies that suggest that the development of tourism needs a network approach, by allowing destinations to be able to function in a changing and complex world [14,15]. The network is defined by Hall [16] (p. 179) as "an arrangement of inter-organization cooperation and collaboration". In the literature on the subject, several positive values are attributed to tourist networks; "it allows to organize and integrate tourism destinations, cause benefits for participating tourism firms, enhance destination performance and quality and stimulate the provision of wholesome and memorable experiences for tourists" [17] (p. 98). Therefore, the network approach to the development of the CBT allows to create, develop and promote this kind of tourism and, at the same time, it serves to structure the relationship between the local community and the visitors. In this sense, decision-making and the development of CBT "requires of the participation of multiple stakeholders at all levels of planning and policy formulation, bringing together governments, NGOs, residents, industry and professionals in a partnership that determines the amount and type of tourism that a community wants. "[18] (p. 1275).

The scientific literature on community tourism is developed based on communities located on different continents, such as Asia [19,20], Oceania [21], Africa [22-24] and Latin America, investigations were carried out in Brazil [25], Mexico [26], Peru [27]. In the specific case of Ecuador, experiences in community tourism were mainly investigated from a qualitative perspective [28-32]. An interesting bibliometric review on the subject can be seen in Álvarez-García et al. [33]. There is no doubt that research is very scarce and necessary and it is this fact that drives this research; it is necessary to understand and realize how the community subject plans, organizes and controls CBT, based on the criteria that emerge from the culture itself and ways of viewing life, to achieve improved community living conditions under the pretext of doing tourism [34]. The objective of this investigation is to carry 
out a detailed study of the ventures identified within continental Ecuador of the communities affiliated to the Plurinational Federation of Community Tourism of Ecuador (FEPTCE).

First, a brief introduction that leads in which the objective of the investigation is exposed and in the second section is collected a review of the literature in which the context of the CBT is exposed; definition, relationship with sustainability and governance through the network. In the third section, the bases of the study are established based on the vision of the FEPTCE and all the active ventures associated with the provincial and cantonal networks of the FEPTCE are detailed. To conclude, Section 4 details the main conclusions of the research.

\section{Literature Review}

\subsection{Community-Based Tourism}

The development of alternatives to traditional tourism led to the use of different elements, including culture and nature; from which different forms of tourism such as community tourism or community-based tourism (CBT) are created, today both concepts are used interchangeably. In this sense, there are several researchers who propose CBT as a development model that allows maximizing the socioeconomic benefits of tourism and minimizing negative environmental impacts $[35,36]$. In the specific case of Andean Latin America, taking advantage of current social dynamics in communities increases this form of tourism.

To understand the concept, it is necessary to carry out a literature review. For Rocharungsat [37] (p. 62) "the CBT is not a construct created from classrooms or academic circles, but a concept that has been forged from certain realities, tourism practices and programs of global reach". Thus, this construct according to Hiwasaki [7] arises in a double world context: "(1) Through actions that promote forms of responsible and sustainable tourism; and (2) for the conservation and management efforts of protected natural areas, which link biodiversity conservation and local community development" [7] (p. 677).

The first time that the term community tourism is mentioned in writing is in the book Tourism: a community approach by Murphy [10], where the term is related to tourism that takes place within disadvantaged rural areas. Later, Brohman [38] (p. 60) provides one of the most comprehensive definitions of CBT:

“Community-based tourism development would seek to strengthen institutions designed to enhance local participation and promote the economic, social and cultural well-being of the popular majority. It would also seek to strike a balanced and harmonious approach to development that would stress considerations such as the compatibility of various forms of development with other components of the local economy; the quality of development, both culturally and environmentally; and the divergent needs, interests and potentials of the community and its inhabitants."

Goodwin and Santilli [39] defined CBT "as tourism owned and/or managed by communities and intended to deliver wider community benefit" and in the specific case of Ecuador, FEPTCE defines it as: the relationship of the community with visitors from an intercultural perspective in the development of organized trips with the consensual participation of its members, guaranteeing the adequate management of natural resources, the valuation of their heritage, the cultural and territorial rights of nationalities and towns for the equitable distribution of the benefits generated [40]. The most widely accepted definitions establish that a high degree of control and a significant proportion of the benefits should be in the hands of members of local communities [41-44].

Years later and based on numerous studies, a relationship was generated between CBT and tourism against poverty or also known as pro-poor tourism (PPT), whose approach was to analyze the influence that tourism has on the community in order to fight against the poverty of spaces [45]; community benefit tourism [46] or community tourism with donor assistance [47]. Following this line, Cabanilla [48] performs a bibliographic review of the concept and identifies other typologies that 
range from the identification of indigenous or ethnic tourism in 1989, to aboriginal tourism in 1993, to go on to link this with ecotourism in the 2000s. All of these are classified as partial approaches because they only study the economic or social aspect and not all the approaches from which CBT can be addressed [37].

To understand CBT, it is necessary to specify that the community is intertwined with tourism, from which two perceptions emerge. On one hand, tourism as an alternative which can generate an economic boost [49], that contributes to increasing income by using the resources available in spaces. Moreover, on the other hand, the community is considered an ethos that arises from the interaction of space, time, social (understanding of family members and relationships), economic (reciprocity models) and political (designation of authorities, decision-making, governance structures) functionality [29,50-52]. This consolidates the community's operating structure, which is why not every human group can be considered a community [53], because the community develops a systemic construction that allows it to have a particular way of life (social relationship levels, capacity for self-organization and collective action), but with a shared understanding [54], which is a feature that is established as the "epistemological foundation of the community experience" [50] (p. 401).

Thus, currently CBT is based on what was mentioned by Fernández [53], who makes it clear that this form of tourism is "the community in tourism and not so much, tourism in the community" (p. 400); that is, it is a form of tourism that allows for the conservation of natural heritage and revitalization of culture, at the same time as achieving the integration and participation of the local community in the tourist management of the territory [55].

There are many benefits, including the economic benefits, already mentioned above, of community tourism, but it is also worth mentioning the damages that can be attributed to tourism, caused in many cases by unplanned growth in tourism, such as environmental degradation, negative cultural and social impacts and habitat fragmentation $[11,56,57]$. These adverse effects lead to a growing concern for the conservation and preservation of natural resources, human well-being and the long-term economic viability of communities [57-60].

In this context, it is inevitable to highlight the close relationship between CBT and sustainable tourism, emerging as a new approach sustainable community tourism $(\mathrm{SCT}$, ) alternative to the traditional neoclassical model of economic development [18] (p. 1274). The CBT model comprises social, environmental and economic axes [57], by encouraging the participation of local residents in the operation and management of tourism projects. Projects where host communities become the main actors by exchanging their ways of life, in which the natural and cultural heritage are valued and protected, while at the same time promoting respect for these resources, becoming a means to improve quality of life, in addition to providing an alternative source of income for community members.

CBT has become a bottom-up strategy for sustainable local development [61], characterized by a series of radical changes that begin when communities are considered objects of attraction and not active subjects of their development [32], to then move on to what was proposed by Pretty [62], who establishes it as "an inverted pyramid mode" (p. 42). In other words, over time, "interactive participation" has been achieved with a high degree of empowerment, based on the active participation of the population and the generation of a systemic community learning process, which allows for well-supported decision-making.

As already mentioned above, to implement this type of tourism, association agreements are required that are formalized through the concept of "network" [63-65], collected in various definitions of the concept $[41,42,44,66]$. The implementation and management of sustainable tourism and especially CBT requires the participation of many stakeholders, both from the public and private sectors (tourism and hospitality companies). As a tool to achieve this objective, the approach of adapting the network perspective to tourism emerges as a new governance structure $[67,68]$ to which many benefits are associated with build profitable tourist destinations; learning and exchange; business activity; and community [69]. In Johns et al. [70] the benefits of governance through networks, as well as the key factors for their success, can be seen in detail: structure and leadership; an established trust culture; 
resourcing; member engagement; inter-organizational learning; underlying objectives; sustainable nature and lifecycle [71-73].

Regarding research related to community-based tourism, this is carried out by numerous researchers in Communities located on different continents and countries. These studies have been identified by Casas Jurado et al. [74] and Dodds et al. [75]. Among others we mention: Costa Rica [76], Peru [27], Kenya Nomadas. [23,77], Japan [7,78], Australia [21], Belize [79], Botswana [80], Hawaii [81], China [82], Italy [83], Turkey [84], Thailand [85], Romania [86], Uganda [22], Namibia [87], Dominica [88], Tanzania [89], Canada [90], Cape Verde [91], Cambodia [92], India [93], South Africa [94], Fiji [95], Madagascar [96], Taiwan [97], Canada [98].

\subsection{Community Tourism in Ecuador}

It begins in the $80 \mathrm{~s}$, as an activity embedded in ecotourism [32] and parallel to the development of traditional tourism. The integration of the tourism activity into communities derives from the search for other mechanisms for the subsistence and preservation of the territories that were being devastated by extractive activities [61,99]. In its beginnings, the activity faces great challenges such as the stereotyping of the worldview and sacred customs of the peoples, as well as cataloguing the communities as cheap labor by national and international private tourism companies. These companies were not interested in bringing benefits to these communities [32], but instead in continuous exploitation of spaces for private benefit.

In rejection of this situation, fights for the vindication of the rights begin. First, CBT is formalized for the first time when it was included in 2001 in the ecotourism and Sustainability Regulations [8]. One year later, communities were integrated as tourism service providers within the tourism law [100], a condition that was prohibited until then. During that same year, through Ministerial Agreement No. 20,020,059 of 11 September 2002, the Plurinational Federation of Community Tourism of Ecuador (FEPTCE) was born, which currently groups various community tourism initiatives of different peoples and nationalities settled in the four natural regions of Ecuador. The general purpose of this organization is to promote and strengthen CBT initiatives to improve the quality of life of communities, from a comprehensive perspective that is viable and sustainable as identity, representing them at national and international levels [40].

In the following years and with some inconveniences involved, the Regulation for the Community Tourist Centers is issued through Agreement No. 2006-0014 of the Ministry of Tourism of Ecuador (MINTUR), which develops a response different from the one expected, that is, it produces a Declaration of Civil Disobedience by the FEPTCE, because it "neither responds to the social reality nor to the legal reality of Ecuadorian community tourism" [101].

This voice of protest allows for the integration of the FEPTCE as a strategic actor in the tourism law and the sustainable tourism development plan of Ecuador (PLANDETUR) 2020, allowing it to lead most of the actions related to CBT. At the same time, it manages to establish that CBT be understood as "the relationship between the community and its visitors from an intercultural perspective, in the context of package tours, with the consensual participation of its members, guaranteeing an adequate management of natural resources, the valuation of their assets, the cultural and territorial rights of nationalities and peoples, for the equitable distribution of the benefits generated" [40]. In other words, it is an alternative that fights traditional mass tourism, presenting the population as "subjects" and not "objects" of their development [99].

\subsection{Plurinational Federation of Community Tourism of Ecuador (FEPTCE)}

This organization is established as the first formal community tourism network on the continent [102], which, in order to achieve the definition indicated above, sets out five pillars for understanding the term COMMUNITY as shown in Figure 1. 


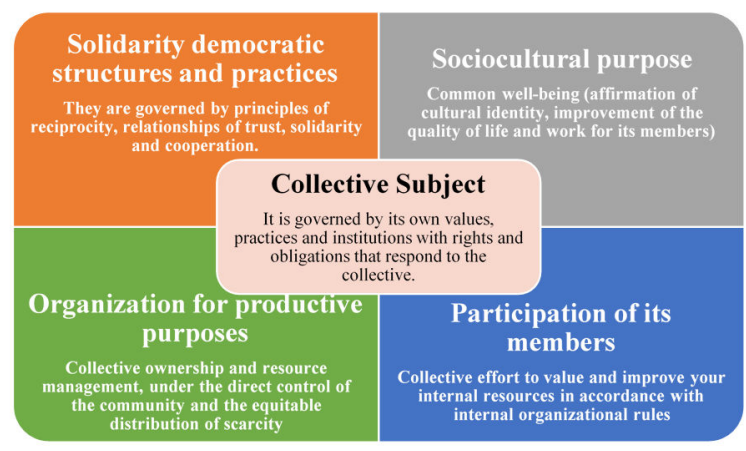

Figure 1. Pillars for understanding the community by the Plurinational Federation of Community Tourism of Ecuador (FEPTCE). Source: FEPTCE [40].

The coordination of these pillars, in turn, will translate into four axes of the CBT work (Figure 2), that seek to: (1) manage and defend the territories inhabited by the peoples and nationalities of Ecuador; (2) generate benefits through CBT by preserving and protecting the natural and cultural heritage, inherited by the community; (3) value the culture, based on the understanding of the reality of the community in synchronous and asynchronous dimensions and how these can be shared, learned and bequeathed to the members; and (4) strengthen the organization to continue claiming its rights.

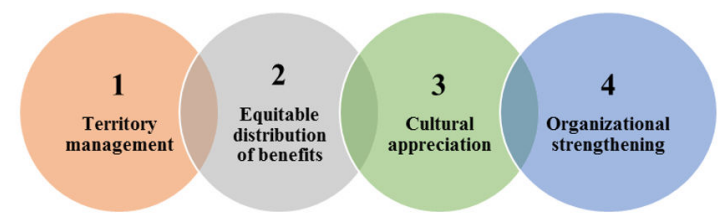

Figure 2. Axes of work of the community-based tourism (CBT) by the FEPTCE. Source: Plurinational Federation of Community Tourism of Ecuador [103].

Another relevant element that supports the work carried out on CBT of Ecuador is the socio-organizational structure of four-level concentric circles, which supports the development of CBT initiatives associated with it (Figure 3).

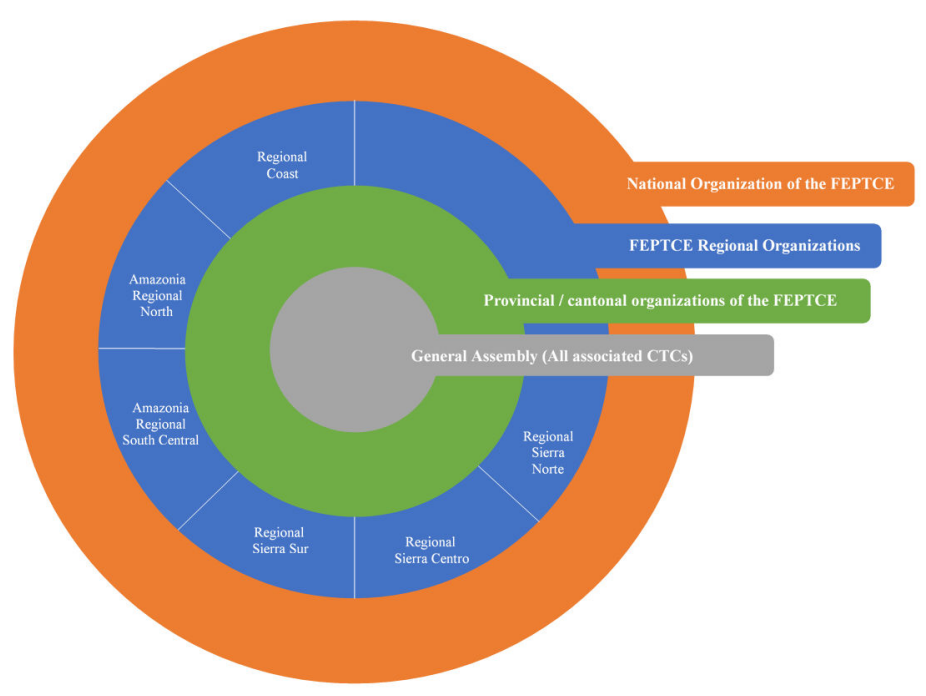

Figure 3. FEPTCE organizational structure. Source: FEPTCE [40].

The structure starts from a central nucleus that is based on a national assembly in which all the community ventures or community tourism centers (CTC) are located, leaving the highest levels of 
organization to the extremes, determining that decisions are made starting from the nucleus or base, which is considered a technical support council.

\subsubsection{Community Ventures That Make up the National Assembly of the FEPTCE}

The FEPTCE emerged from the postulates proposed in the event "Sustainable and Competitive Tourism Management: Alliances between the State" held in the city of Otavalo, Ecuador, from 12th to 14th September 2001 [104]. The proposals to "promote in each of the countries and at regional level the institutionalization of a "community tourism network" that promotes community tourist destinations, ensuring their authenticity and sustainability" stand out; in addition to "institutionalizing and supporting the execution of community tourism within the framework of the collective rights of indigenous peoples" [105] (p. 71).

As of this, in 2002, the Manduriacos Community Ecotourism Committee, the Runa Tupari Cía, Ltd. Operating Agency, The Ingapirca Institute of the Cañari People (IIPC), the Indigenous Network of Communities of the Alto Napo for Intercultural Coexistence and Ecotourism (RICANCIE) and the Organization of the Indigenous Peoples of Pastaza (OPIP) organize themselves for the founding process of the FEPTCE, which at that time are developing tourist activities registered by MINTUR, but not under a community tourism name [102]. Thus, the FEPTCE begins with five participating initiatives.

In the following years, a participatory process is proposed within Ecuador, which the FEPTCE was part of, with the purpose of building PLANDETUR for the year 2020, in which it is maintained that the actors directly involved with tourism are private, community and public sectors [106], registering a total of 30 initiatives under the CTC form [106,107].

Community tourism continues its positioning at country level and for 2010, Yuctor [108] presents an analysis of the FEPTCE's community tourism offer of the five regional organizations, detailing a total of 117 initiatives, without specifying those that are recognized as CTC.

Finally, in an analysis of both physical and digital secondary sources, a refined list is obtained for 2020 of 121 community tourism initiatives (Table 1), of which only 83 are active, which were contrasted with official data of CTC of MINTUR [109]. Figure 4 shows the distribution of the initiatives within the continental territory.

Of the 83 initiatives identified as active, only 22\% (18) are categorized as consolidated initiatives, as they are legally constituted and have all the corresponding requirements and permits to be registered CTC (Table 1); the rest of the initiatives are established in the consolidation process or as new initiatives according to the types of tourism ventures created by Ochoa [110].

At this point, it is necessary to clarify that according to figures of the National Tourist Cadastre of Establishment of MINTUR [109], at country level, there are a total of 39 CTC, distributed in 14 of the 23 provinces of the continental territory, of which $28 \%$ are linked to the FEPTCE.

\subsubsection{Community Ventures That Make up the National Assembly of the FEPTCE}

According to Cabanilla \& Garrido [102], there are 16 community tourism networks and operators in the country, of which nine $(56.25 \%)$ are part of the FEPTCE, while seven $(43.75 \%)$ are established as independent (Figure 4). 
Table 1. Community enterprises recognized by the FEPTCE in the Year 2020.

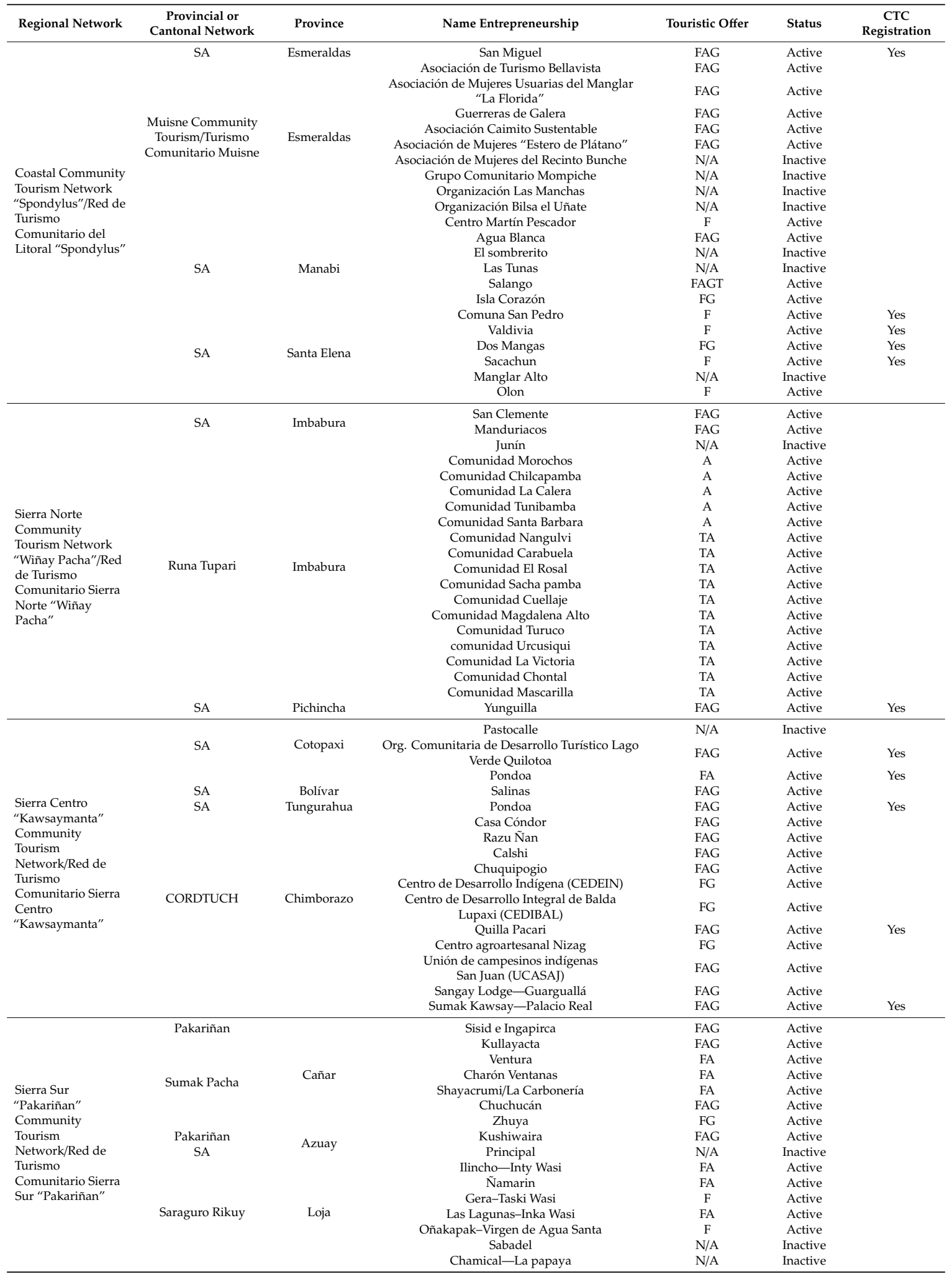


Table 1. Cont.

\begin{tabular}{|c|c|c|c|c|c|c|}
\hline Regional Network & $\begin{array}{c}\text { Provincial or } \\
\text { Cantonal Network }\end{array}$ & Province & Name Entrepreneurship & Touristic Offer & Status & $\begin{array}{c}\text { CTC } \\
\text { Registration }\end{array}$ \\
\hline \multirow{28}{*}{$\begin{array}{l}\text { Community } \\
\text { Tourism Network } \\
\text { Amazon/Red de } \\
\text { Turismo } \\
\text { Comunitario } \\
\text { Amazonía }\end{array}$} & SA & \multirow{11}{*}{ Napo } & Pacto Sumaco & FAG & Active & \multirow{9}{*}{ Yes } \\
\hline & \multirow{9}{*}{ RICANCIE } & & Salazar Aitaka & N/A & Inactive & \\
\hline & & & Waysa Yaku de Alukus & FAG & Active & \\
\hline & & & Takik Sacha & N/A & Inactive & \\
\hline & & & Chuva Urku & N/A & Inactive & \\
\hline & & & Limoncocha & FA & Active & \\
\hline & & & Runa Wasi & FAG & Active & \\
\hline & & & Río Blanco & FAG & Active & \\
\hline & & & Wasila Talag & FAG & Active & \\
\hline & & & Sinchipura & FA & Active & Yes \\
\hline & SA & & Shiripuno & FA & Active & Yes \\
\hline & SA & \multirow{12}{*}{ Pastaza } & Sinchi warmi & FAG & Active & \multirow[t]{13}{*}{ Yes } \\
\hline & SA & & Valle Hermoso & N/A & Inactive & \\
\hline & Community Tourist & & Ceploa & FA & Active & \\
\hline & Centers of the & & Shiwa Kucha & N/A & Inactive & \\
\hline & Arajuno canton/Red & & Shikulin & N/A & Inactive & \\
\hline & de Centros Turísticos & & San Vicente & N/A & Inactive & \\
\hline & \multirow{7}{*}{$\begin{array}{l}\text { Comunitarios del } \\
\text { cantón Arajuno }\end{array}$} & & Elena Andi de Oglan & N/A & Inactive & \\
\hline & & & Pituk Yacu & N/A & Inactive & \\
\hline & & & Suyu Pakcha & N/A & Inactive & \\
\hline & & & Santa Cecilia de Villano & $\mathrm{N} / \mathrm{A}$ & Inactive & \\
\hline & & & Pantiin Shiram & N/A & Inactive & \\
\hline & & & Comuna Kichwa Sani Isla & $\mathrm{F}$ & Active & \\
\hline & & & Ishpingo Pakcha & FAG & Active & \\
\hline & SA & Orellana & Sacha Nampi & FAG & Active & \multirow[t]{4}{*}{ Yes } \\
\hline & & & Tambo Caspi Lodge & FAG & Active & \\
\hline & & & Yaku Warmi & N/A & Inactive & \\
\hline & SA & & Tutupali & N/A & Inactive & \\
\hline
\end{tabular}

SA—without provincial or cantonal association; N/A—does not apply; FAGT—food, accommodation, guidance and transportation; FAG—food, accommodation and guidance; FA—food and accommodation; FG—-food and guidance; F-food; A-accommodation; TA—tourist activities.

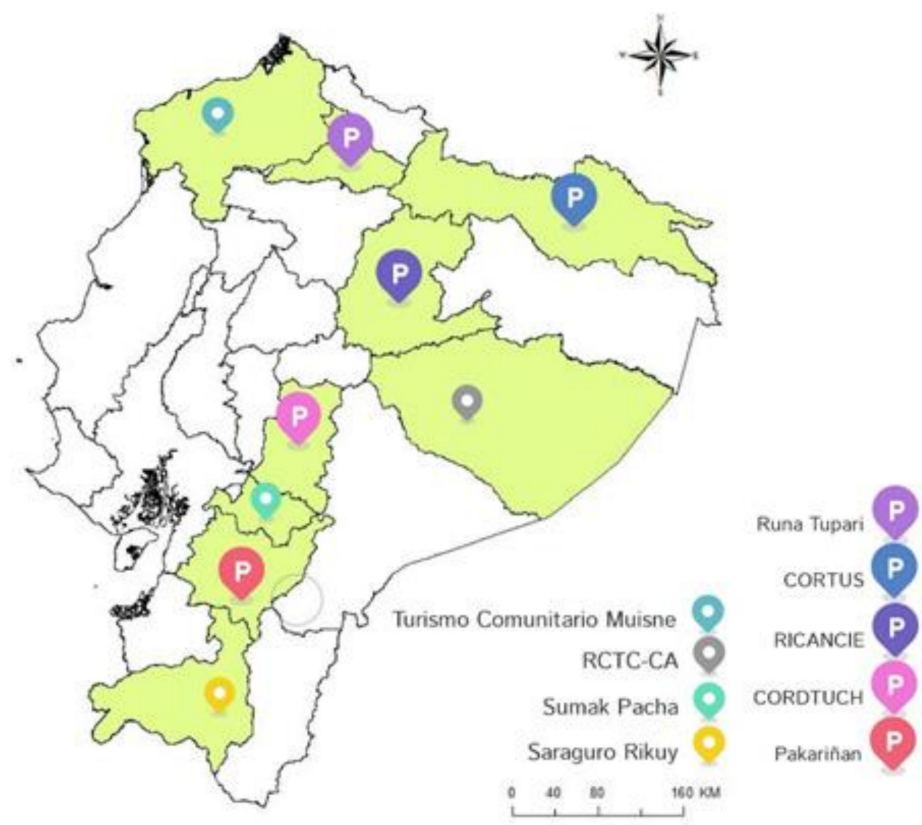

Figure 4. Geographic distribution of the provincial/cantonal networks of the FEPTCE. 


\section{Provincial/Cantonal Networks of the FEPTCE}

\subsection{Muisne Community Tourism}

The Foundation of Ecological Defense (FUNDECOL) is located in the south of the Esmeraldas province, in the Muisne canton. It begins with the purpose of generating measures for the protection of the province's mangrove forests [111], which present constant threats of indiscriminate deforestation by extractive activities such as the shrimp industry [40], as well as by sun and beach tourism that has gradually modified the coastal profiles to expand the extension of beaches for tourists [112]. These actions threatened the ancestral territories of human groups made up of members of the Chachi, Afro-Ecuadorian and mestizo people [40].

In this way, FUNDECOL together with the action of organizations such as C-CONDEM, FUEMBOTH-M [112] and traditional mangrove users have started with the development of community tourism as an activity capable of contributing to raising awareness of the general population on the defense of mangrove forests [111].

This type of tourism began in 1989 and was settled in 1992 [40], with the participation of families from the towns of Bilsa, Las Manchas, Mompiche, Daule and Bolívar, which are organized in various community initiatives focused on the sustainable use of their territories [112,113]. It should be noted that after a thorough documentation review, it was observed that this network emerged with the name of FUNDECOL and sometime later it was renamed Muisne Community Tourism-FUNDECOL, to currently be known only as Muisne Community Tourism.

The Mache Chindul Ecological Reserve and the Manglares Estuary River Muisne Wildlife Refuge are within the area of influence of the ventures associated with the network, spaces dominated by ecotourism activities. These ventures have received the support of several NGOs at international level since the 1990s, but as Cabanilla [112] indicates, the ventures associated with what was originally FUNDECOL show an absence of adequate basic services, security problems and precarious facilities that prevent the consolidation of this tourist offer, which is why they have not been able to form part of the MINTUR National Tourist Cadastre of Establishment.

Currently, this network launched an organizational strengthening process in order to strengthen the community bases in the area and thereby ensure that the traveler can enjoy a unique experience, which cannot be surpassed by any tour operator [114] (Tables 2 and 3). In 2009, the company Martín Pescador was created in the city of Quito: Product Marketing Center and Revaluation of the Culture of the Mangrove Ecosystem, with the purpose of bringing mangrove products that are extracted with protection and quality measures to other people, whereby it is possible to transmit "the fight for the recovery, conservation and defense of the mangrove ecosystem that is a heritage of all Ecuadorians" [112,115].

Table 2. Community enterprises associated with Community Tourism Muisne/Turismo Comunitario Muisne.

\begin{tabular}{|c|c|c|}
\hline Location & Entrepreneurship & Marketing Approach \\
\hline Esmeraldas & $\begin{array}{c}\text { Asociación de Turismo Bellavista } \\
\text { Asociación de Mujeres Usuarias del Manglar } \\
\text { "La Florida" } \\
\text { Guerreras de Galera } \\
\text { Asociación Caimito Sustentable } \\
\text { Asociación de Mujeres “Estero de Plátano" } \\
\text { Centro Martín Pescador }\end{array}$ & $\begin{array}{l}\text { A different and innovative concept of } \\
\text { tourism. Small rural communities share } \\
\text { their homes with tourists and allow } \\
\text { them to learn about their customs, daily } \\
\text { life and ancestral knowledge. }\end{array}$ \\
\hline
\end{tabular}

Only active entrepreneurships are described. Source: Tourism Muisne [114]; FEPTCE [40]. 
Table 3. Product lines and tourist activities for community entrepreneurship associated with Community Tourism Muisne/Turismo Comunitario Muisne.

\begin{tabular}{|c|c|c|c|c|c|c|c|}
\hline 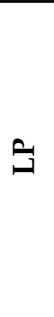 & Activities & 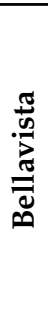 & 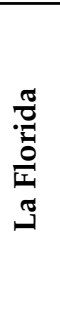 & $\frac{\pi}{\frac{\pi}{\pi}}$ & 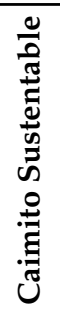 & 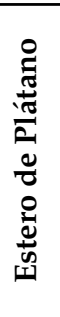 & 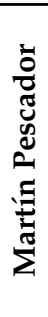 \\
\hline \multirow{10}{*}{$\bigcup_{I=1}^{U}$} & Visit to the Mangrove forest & $\mathbf{x}$ & $\mathbf{x}$ & & & & \\
\hline & Artisanal canoe ride & $\mathbf{x}$ & & & & & \\
\hline & Visit to community beaches & $\mathbf{x}$ & & & $\mathbf{x}$ & $\mathbf{x}$ & \\
\hline & Boat tours & & $\mathbf{x}$ & $\mathbf{x}$ & & & \\
\hline & Observation of native and endemic bird species & & $\mathbf{x}$ & & & & \\
\hline & Observation of native and endemic flora species & & & & $\mathbf{x}$ & & \\
\hline & Visit the Faro de Galera & & & $\mathbf{x}$ & & & \\
\hline & Enjoy cliffs and seascapes & & & & $\mathbf{x}$ & $\mathbf{x}$ & \\
\hline & Humpback Whale Watching & & & $\mathbf{x}$ & $\mathbf{x}$ & $\mathbf{x}$ & \\
\hline & Forest walks & & & & $\mathbf{x}$ & $\mathbf{x}$ & \\
\hline \multirow{4}{*}{ U } & Preparation and tasting of traditional foods and drinks & $\mathbf{x}$ & $x$ & $\mathbf{x}$ & $\mathbf{x}$ & $\mathbf{x}$ & $\mathbf{x}$ \\
\hline & Collection of shells and other mollusks in the mangrove swamp. & & $\mathbf{x}$ & & & & \\
\hline & Artisanal fishing practice & & $\mathbf{x}$ & & & & \\
\hline & Octopus catch on rocky beaches & & & & & $\mathbf{x}$ & \\
\hline
\end{tabular}

\subsection{Runa Tupari}

Interaction between communities in the province of Imbabura emerged as a form of vindication of rights and as a response against abuses and overexploitation of the work that the mestizo population carried out on the indigenous population [116]. One of the first actions that marked the change was the constitution of the Union of Peasant and Indigenous Organizations of Cotacachi (UNORCAC) in 1980, a second-degree organization that groups 46 communities and several peasant and indigenous based organizations, on a nonprofit basis [117].

In the following years, UNORCAC worked in different areas for the development of communities, among them the tourist activity, for which a tourism project was formulated that received the technical and financial support of the Dutch NGO Agritierra; in addition to training for and promoting the project by INIAP, CODESARROLLO and the Italian NGO CODEP [118].

Based on this background for 2001, the decision was to create the Runa Tupari Community Tourism Operator, under the alliance of five partners: UNORCAC and four indigenous communities in the Cotacachi canton (Morochos and Chilcapamba, which were the first to participate, followed by Tunibamba and La Calera) [116]; conceived as a limited liability company capable of managing the tourism project that UNORCAC had started, in addition to offering and promoting package tours that include community tourism ventures of local providers [116,117].

The name of this operator translated from Kichwa means "Meeting of indigenous people", which is constituted as a subsidiary organization of the FEPTCE. The operator bases its business management on community elements, with clear participation rules formulated that minimize risks and contribute to equity in income distribution [116]. It must be pointed out that all the operator's profits are reinvested in the participating communities through the management of councils or UNORCAC [119]. All this turns the local tourist activity into a much more human action, which reinforces the bidirectional cultural meeting process, a fact that, on one hand, allows guests to live in interculturality, and on the other hand, to learn about other ways of understanding the world $[40,119]$. 
The operator has been recognized with several awards, including the Merit Recognition by the Ministry of Tourism of Ecuador (2008) and the PACHAMAMA Quality Seal (2012) [119]. Regarding the range of products, it is wide and varied, allowing tourists to get to know the Imbabura area, as well as connecting it with different areas of the northern highlands, in addition to the other regions of the country.

The offer of the ventures also includes volunteer programs focused on areas of education, conservation, micro-businesses, fair trade, among others (Tables 4 and 5). Two options of stays are offered: long stay (minimum of 15 to 45 days) aimed at small groups or individuals, which are designed according to the professional experience, interest and demand of the organizations that make up the opposing party; or short stays (minimum of two days) for larger groups, which focus on community work together with the entire community, for example, a minga or the group's professional capacities are taken advantage of to solve a problem that communities face [119].

Table 4. Community enterprises associated with Runa Tupari.

\begin{tabular}{cccc}
\hline Location & \multicolumn{2}{c}{ Entrepreneurship } & Marketing Approach \\
\hline & San Rafael Community & El Rosal Community & \\
& Chilcapamba Community & Sacha Pamba Community & Cultural exchange based on \\
& La Calera Community & Cuellaje Community & the active participation of \\
& Tunibamba Community & Magdalena Alto Community & community members who \\
Imbabura & Santa Barbara Community & Turuco Community & explain their work, \\
& Nangulvi Community & Urcusiqui Community & demonstrate their arts and \\
& Carabuela Community & La Victoria Community & share their culture. \\
& Mascarilla Community & Chontal Community & \\
\hline
\end{tabular}

Source: Runa Tupari [119]; Runa Tupari [120].

The tourist offer of the packages promoted by Runa Tupari is developed by most of the communities through a rotation system for receiving visitors. Depending on the season, it can be offered by any community, since the provision of services focuses on providing an authentic vision of the daily life of indigenous families, to avoid offering a show of staged and stereotyped cultures. Therefore, all the common activities have been associated with the tour operator within Table 5.

\subsection{CORDTUCH}

With a 13-year history, it began in 1998 under the name of Chimborazo Community Tourism Organization (ORTUCH). In 2012 it changed to Chimborazo Community Development and Tourism Organization, and finally, in 2016 it was consolidated under the name of Corporation for Community Tourism Development of Chimborazo (CORDTUCH). In addition to this, the tour operator Puruha Razurku Cia., Ltd. was created in 2006 [121].

This network stands out for maintaining a range of products linked to the Chimborazo Fauna Production Reserve, which houses the highest snow-capped mountain in Ecuador and the point on the earth closest to the sun. Eleven initiatives from both peasant and indigenous organizations arise from it, distributed in five cantons of the Chimborazo province: Riobamba (4), Guano (3), Colta (2), Guamote (1) and Alausí (1). 
Table 5. Product lines and tourist activities by community enterprise associated with Runa Tupari.

\begin{tabular}{|c|c|c|c|c|c|c|c|c|c|c|c|c|c|c|c|c|c|c|c|}
\hline 3 & Activities & 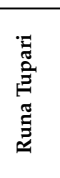 & 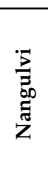 & 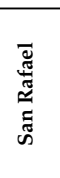 & 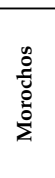 & 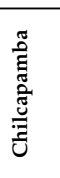 & 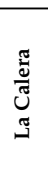 & 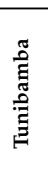 & 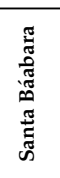 & 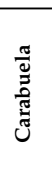 & 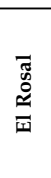 & 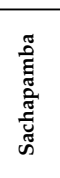 & $\frac{\frac{0}{\pi}}{\bar{\Xi}}$ & 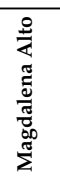 & $\underset{8}{\stackrel{g}{g}}$ & 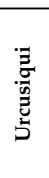 & 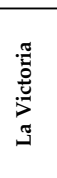 & 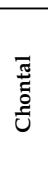 & 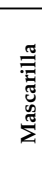 \\
\hline \multirow{22}{*}{ Uु } & Visit to the nearby cities (Cotacachi, Otavalo, etc.) & $\mathrm{x}$ & & $x$ & $x$ & $\mathrm{x}$ & $\mathrm{x}$ & $\mathrm{x}$ & $\mathrm{x}$ & $\mathrm{x}$ & & & & & & & & & \\
\hline & Visit to the craft market "Plaza de Ponchos" & $\mathrm{x}$ & & & & & & & & & & & & & & & & & \\
\hline & Visit to ceramic workshops & & & & & & & & & & & & & & & & $\mathrm{x}$ & & \\
\hline & Visit of mask workshops & & & & & & & & & & & & & & & & & & $\mathrm{x}$ \\
\hline & Participation in gardening work & $\mathrm{x}$ & & $\mathrm{x}$ & $\mathrm{x}$ & $\mathrm{x}$ & $\mathrm{x}$ & $\mathbf{x}$ & $\mathrm{x}$ & & & & & & & & & & \\
\hline & Enjoy play with the kids & $\mathrm{x}$ & & $\mathrm{x}$ & $\mathrm{x}$ & $\mathrm{x}$ & $\mathrm{x}$ & $\mathrm{x}$ & $\mathrm{x}$ & & & & & & & & & & \\
\hline & Walks or walks around the community & $\mathrm{x}$ & $\mathrm{x}$ & $\mathrm{x}$ & $\mathrm{x}$ & $\mathrm{x}$ & $\mathrm{x}$ & $\mathbf{x}$ & $\mathrm{x}$ & & & & & & & $\mathrm{x}$ & & & \\
\hline & Soccer practices against adolescents & $\mathrm{x}$ & & $\mathrm{x}$ & $\mathrm{x}$ & $\hat{x}$ & $\mathrm{x}$ & $\mathrm{x}$ & $\mathrm{x}$ & & & & & & & & & & \\
\hline & Participation in cooking workshops together & $\mathrm{x}$ & & $\mathrm{x}$ & $\mathrm{x}$ & $\mathrm{x}$ & $x$ & $\mathbf{x}$ & $\mathrm{x}$ & & & & & & & & & & \\
\hline & Preparation of family holidays & $\mathrm{x}$ & & $\mathrm{x}$ & $\mathrm{x}$ & $\mathrm{x}$ & $\mathrm{x}$ & $\mathrm{x}$ & $\mathrm{x}$ & & & & & & & & & & \\
\hline & Coexistence with host families & $\mathrm{x}$ & & $\mathrm{x}$ & $\mathrm{x}$ & $\mathrm{x}$ & $\mathrm{x}$ & $\mathrm{x}$ & $\mathrm{x}$ & & & & & & & & & & \\
\hline & Visit to the musical instruments workshop & & & $\mathrm{x}$ & & & & & & & & & & & & & & & \\
\hline & Visit of artisan fabrics workshop & & & & & & & & & $\mathrm{x}$ & & & & & & & & & \\
\hline & Visit to the jewelry workshop with natural materials & & & & & & $\mathrm{x}$ & & & & & & & & & & & & \\
\hline & Visit to the workshop of crafts made of cattails & & & $\mathrm{x}$ & & & & & & & & & & & & & & & \\
\hline & Visit to traditional markets & $\mathrm{x}$ & & & & & & & & & & & & & & & & & \\
\hline & Visit to the production of handicrafts of Cabuya & $\mathrm{x}$ & & & & & & & & & & & & & & & & & \\
\hline & Manufacture of products based on Aloe Vera & & & & & & & & & & $\mathrm{x}$ & & & & & & & & \\
\hline & Visit to the Chota Valley & $\mathrm{x}$ & & & & & & & & & & & & & & & & & \\
\hline & Learning of Afro-Ecuadorian culture & $\mathrm{x}$ & & & & & & & & & & & & & & & & & \\
\hline & Tour on the Freedom Train & $\mathrm{x}$ & & & & & & & & & & & & & & & & & \\
\hline & Visit to the Salt Museum & $\mathrm{x}$ & & & & & & & & & & & & & & & & & \\
\hline \multirow{6}{*}{ E } & Explanation and demonstration of midwives & $\mathrm{x}$ & & & & & & & & & & & & & & & & & \\
\hline & Visit to an indigenous shaman & $\mathrm{x}$ & & & & & & & & & & & & & & & & & \\
\hline & Visit to the Ethnobotanical Garden & $\mathrm{x}$ & & & & & & & & & & & & & & & & & \\
\hline & Explanation about medicinal plants & $\mathbf{x}$ & & & & & & & & & & & & & & & & & \\
\hline & Visit to the Chachimbiro thermal tourist complex & $\mathrm{x}$ & & & & & & & & & & & & & & & & & \\
\hline & Visit to the Nangulvi Thermal Resort & & $\mathrm{x}$ & & & & & & & & & & & & & & & & \\
\hline \multirow{18}{*}{ S } & Visit to the Intag Valley & $\mathrm{x}$ & & & & & & & & & & & & & & & & & \\
\hline & Learning of coffee cultivation in Apuela & $\mathrm{x}$ & & & & & & & & & & & & & & & & & \\
\hline & Visit of the Alpacas trail & $\mathrm{x}$ & & & & & & & & & & & & & & & & & \\
\hline & Alpacas maintenance demonstration & $\mathrm{x}$ & & & & & & & & & & & & & & & & & \\
\hline & Horseback riding in the community & & & & & & $\mathbf{x}$ & & & & & & & & & & & & \\
\hline & Visit to the Peguche waterfall & $\mathrm{x}$ & & $\mathrm{x}$ & & & & & & & & & & & & & & & \\
\hline & Visit to the Cuicocha Lagoon & $\mathrm{x}$ & & & & & $\mathrm{x}$ & & & & & & & & & & & & \\
\hline & Visit to the Mojanda Lagoons & $\mathrm{x}$ & & & & & & & & & & & & & & & & & \\
\hline & Hike with pack mules & $\mathrm{x}$ & & & & & & & & & & $\mathrm{x}$ & & $\mathrm{x}$ & & & & & \\
\hline & Sport fishing & $\mathrm{x}$ & & & & & & & & & & & & & & & & & \\
\hline & Visit to Los Cedros private reserve & & & & & & & & & & & & & $\mathrm{x}$ & & & & & \\
\hline & Observation of endemic and native flora and fauna & & & & & & & & & & & & & $\mathrm{x}$ & & & & & \\
\hline & 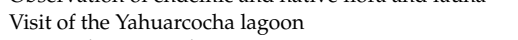 & $\mathrm{x}$ & & & & & & & & & & & & & & & & & \\
\hline & Visit to the Cotacachi-Cayapas Reserve & $\mathrm{x}$ & & & & & & & & & & & & $\mathrm{x}$ & & & & & \\
\hline & Visit to El Angel Ecological Reserve & $\mathrm{x}$ & & & & & & & & & & & & & & & & & \\
\hline & Visit to El Voladero lagoon & $\mathrm{x}$ & & & & & & & & & & & & & & & & & \\
\hline & Sight to microenterprises of crafts, agriculture & & & & & & & & & & & & & $\mathrm{x}$ & & & & $\mathrm{x}$ & \\
\hline & Visit to the Peguche waterfall & $\mathrm{x}$ & & & & & & & & & & & & & & & & & \\
\hline \multirow{8}{*}{ \& } & Walks in páramo, high mountains, cloud forest, etc. & & $\mathrm{x}$ & & & & & & & & $\mathrm{x}$ & & $\mathrm{x}$ & & & & & & \\
\hline & High mountain camping & $\mathrm{x}$ & & & & & & & & & & & & & & & & & \\
\hline & Ascent to the Casha Pampa summit, Fuya mountain, & $\mathrm{x}$ & & & & & & & & & & & & & & & & & \\
\hline & $\begin{array}{l}\text { Yana-urco hill, among others } \\
\text { Wild camping }\end{array}$ & $x$ & & & & & & & & & & $x$ & & & & & & & \\
\hline & Visit to the Piñan Lagoon & $\mathrm{x}$ & & & & & & & & & & & & & & & & & \\
\hline & Mountain biking & $\mathrm{x}$ & & & & & & & & & & & & & & & & & \\
\hline & Road bike tours & & $\mathrm{x}$ & & & & $\mathrm{x}$ & & & & & $\mathrm{x}$ & & & $\mathrm{x}$ & $\mathrm{x}$ & & & \\
\hline & Adventure sports (canopy, rafting, canyoning, etc.) & $\mathrm{x}$ & & & & & & & & & & & & & & & & & \\
\hline
\end{tabular}

The work generated by the organization and community ventures benefits approximately 1700 families, by contributing to the improvement of living conditions; At the same time, it works for claiming the Kichwa as nationality and the Puruhá as peoples, for which they have incorporated strategies for the recovery of elements of the cultural heritage and daily life of the communities [122-124]. The organization groups its tourism products into five lines (Table 6), from which about 22 tourist activities are derived (Table 7). 
Table 6. Community enterprises associated with Corporation for Community Tourism Development of Chimborazo (CORDTUCH).

\begin{tabular}{ccc}
\hline Location & Entrepreneurship & Marketing Approach \\
\hline Casa Condor & \\
Razu Nan & Nature exploration \\
& Sangay Lodge-Guarguallá & \\
Chuquipogio & \\
CEDEIN & Collective and ancestral knowledge \\
UCASAJ & CEDIBAL & Contact or coexistence with living cultures \\
Quilla Pacari & Visit to sacred places and participation in \\
& Sumak Kausay & community practices \\
& Nizag & Visit to monuments and archaeological remains \\
\hline
\end{tabular}

Table 7. Product lines and tourist activities for community entrepreneurship associated with CORDTUCH.

\begin{tabular}{|c|c|c|c|c|c|c|c|c|c|c|c|c|}
\hline 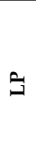 & Activities & 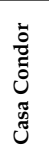 & 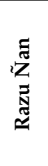 & 蟋 & 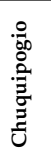 & 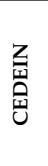 & 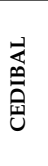 & 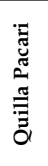 & 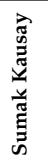 & 宽 & 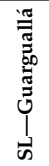 & 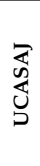 \\
\hline \multirow{4}{*}{ 安 } & Mountain and mountain climbing & $\mathrm{x}$ & $\mathrm{x}$ & & & & & & & & & \\
\hline & Mountain and mountain ascents & $\mathrm{x}$ & $\mathrm{x}$ & & $\mathrm{x}$ & & & & & & $\mathrm{x}$ & \\
\hline & Preparation for mountaineering & & $\mathrm{x}$ & & & & & & & & & \\
\hline & Rock climbing & & & & & & & & & & $\mathrm{x}$ & \\
\hline \multirow{8}{*}{ 画 } & Walks in the community, forest or mountain & $\mathrm{x}$ & $\mathrm{x}$ & $\mathrm{x}$ & $\mathrm{x}$ & & $\mathrm{x}$ & $\mathrm{x}$ & $\mathrm{x}$ & $\mathrm{x}$ & $\mathrm{x}$ & $\mathrm{x}$ \\
\hline & Bike rides & $\mathrm{x}$ & & & & & & & & & & \\
\hline & Horseback riding & & & & & & & & & $\mathrm{x}$ & $\mathrm{x}$ & \\
\hline & Activities in rivers & & & & & & & & & $\mathrm{x}$ & & \\
\hline & Landscape photography & & & & $\mathrm{x}$ & & & & & & & \\
\hline & $\begin{array}{l}\text { Visit of hills, lagoons, Polylepis forest, waterfalls, caves, } \\
\text { natural viewpoints, among other spaces. }\end{array}$ & $\mathrm{x}$ & & & & & & $\mathrm{x}$ & $\mathrm{x}$ & $\mathrm{x}$ & $\mathrm{x}$ & $\mathrm{x}$ \\
\hline & Observation of native and endemic flora & $\mathrm{x}$ & & & & & & & & & & \\
\hline & Observation of native and endemic birds & $\mathrm{x}$ & & & & & & & & & & \\
\hline \multirow{7}{*}{ U } & Visit of monuments and archaeological remains & & & & & & & & & $\mathrm{x}$ & & \\
\hline & Visit to traditional fairs & $\mathrm{x}$ & & & & & $\mathrm{x}$ & & & & & \\
\hline & Visit to ancestral cultural sites & $\mathrm{x}$ & & & & & & & & & & \\
\hline & Visit to local museums & & & & & & & & $\mathrm{x}$ & $\mathrm{x}$ & & \\
\hline & Tasting of local gastronomy & & & & & & & & $\mathrm{x}$ & & & \\
\hline & Visit to the spinning mill & & & & & & & & $\mathrm{x}$ & & & \\
\hline & Sale of handicrafts & & $\mathrm{x}$ & $\mathrm{x}$ & $\mathrm{x}$ & & & $\mathrm{x}$ & $\mathrm{x}$ & & $\mathrm{x}$ & $\mathrm{x}$ \\
\hline \multirow{3}{*}{ 苍 } & Alpaca fiber shearing and treatment activities & $\mathrm{x}$ & & & & & & $x$ & & & & \\
\hline & $\begin{array}{l}\text { Purchase of local products } \\
\text { Share the practice of productive agricultural activities }\end{array}$ & & & & & & $\mathrm{x}$ & & & & & $\mathrm{x}$ \\
\hline & Share the practice of productive crafts activities & & & & & $\mathrm{x}$ & & & $\mathrm{x}$ & & & \\
\hline 皇 & Use and treatment of medicinal plants & & & & & $\mathrm{x}$ & & & & & & \\
\hline \multirow{3}{*}{ 茳 } & Playful moments of coexistence & $\mathrm{x}$ & & & & $\mathrm{x}$ & & & & $\mathrm{x}$ & $\mathrm{x}$ & $\mathrm{x}$ \\
\hline & Participation in traditional festivals & & $\mathrm{x}$ & & & & & & & & & \\
\hline & Community coexistence & $\mathrm{x}$ & $\mathrm{x}$ & $\mathrm{x}$ & & $\mathrm{x}$ & $\mathrm{x}$ & & $\mathrm{x}$ & $\mathrm{x}$ & $\mathrm{x}$ & $\mathrm{x}$ \\
\hline \multirow{3}{*}{5} & Language learning & $\mathrm{x}$ & & & & & & & $\mathrm{x}$ & $\mathrm{x}$ & & \\
\hline & Development of social projects and local production & $\mathrm{x}$ & & & & & & & $\mathrm{x}$ & $\mathrm{x}$ & & \\
\hline & Community tourism strengthening & $\mathrm{x}$ & & & & & & & $\mathrm{x}$ & $\mathrm{x}$ & & \\
\hline
\end{tabular}

The varied tourist offer of the organization's ventures is marketed through Puruha Razurku Cia., Ltd., through three local package tours (Puruha living, Puruha biking, Puruha trekking) and an inter-provincial one that belongs to the Sierra Centro Tour, which joins the ventures of the Chimborazo provinces with the ventures of Salinas de Guaranda, located in the Bolívar province.

In addition, volunteer activities can be carried out within the Sumak Kawsay, Nizag and Casa Cóndor communities. Dual benefits are achieved within these experiences, on one hand, academic and social benefits from the development of research on cultural and agricultural issues and forestry; on the other hand, economic and labor benefits thanks to obtaining assistance for tourist operations and community microenterprises [124]. 


\subsection{Pakariñan}

The Austro Pakariñan Community Tourism Network, which translated from kichwa means Way of Dawn, emerged in September 2005. This network in turn groups two second-degree networks: Community Tourism Network of the Cañari Sumak Pacha people and the Saraguro Ricuy Network, as well as grouping 32 other community organizations and solidarity-based economy ventures related to community tourism activities within the provinces of Cañar, Azuay, Zamora Chinchipe and Loja $[125,126]$. This network is focused on promoting a responsible and sustainable use of resources, avoiding attempts against the life and balance of the environment [127].

In order to facilitate the exchange process and minimize the presence of intermediaries within the marketing chain of its subsidiary organizations, two marketing companies are created: the experiential tourism operator Pakariñan Expeditions and Maki Fairtrade. The former commercializes experiences focused on the transmission of the essence of the four groups linked for community tourism, together with a wide range of ancestral knowledge. In the latter, the exchange of products made with different traditional craftmanship from the intangible and material cultural heritage of various peoples of Ecuador is facilitated (Tables 8 and 9).

Table 8. Community enterprises associated with Pakariñan.

\begin{tabular}{ccc}
\hline Location & Entrepreneurship & Marketing Approach \\
\hline Loja & Namarin & An ancient people \\
Azuay & Kushiwaira & Tradition, culture and work \\
Cañar & Sisid e Ingapirca & The magic of the village Cañari \\
\hline Source: Pakariñan [127];Arévalo and Romero [128]; La Revista [129].
\end{tabular}

Table 9. Product lines and tourist activities for community entrepreneurship associated with Pakariñan.

\begin{tabular}{|c|c|c|c|c|}
\hline G & Activities & Namarin & Sidsid e Ingapirca & Kushiwaira \\
\hline \multirow{9}{*}{ U } & Guided walks & $\mathrm{x}$ & $\mathrm{x}$ & \\
\hline & Excursions to the Inca Bath and the Mirador & $x$ & & \\
\hline & Visit to the Podocarpus National Park & & & \\
\hline & Observation of shells and petrified snails & & & \\
\hline & Observation of native and endemic flora and fauna species & $x$ & & \\
\hline & Hike to the viewpoints Cañaribamba and Ingañán & & & $\mathrm{x}$ \\
\hline & Visit to the Achapana Urcu natural viewpoint & & & $\mathrm{x}$ \\
\hline & Visit to the Culebrillas Lagoon & & $x$ & \\
\hline & Forest walks & & & $\mathrm{x}$ \\
\hline \multirow{5}{*}{ 可 } & Manufacture of traditional food and drinks & & & $\mathrm{x}$ \\
\hline & Sheep wool spinning practice & & $x$ & $x$ \\
\hline & Native music and dance & $x$ & $x$ & \\
\hline & Traditional food, such as Pinzhi, tortillas with colada & $x$ & & \\
\hline & Craft workshops: in mullo, sheep wool and carpentry & $\mathrm{x}$ & & \\
\hline \multirow{3}{*}{ 安 } & Expedition down the Nangaritza River & & & \\
\hline & Visit of the Miazi Canyons & & & \\
\hline & Visit to the Labyrinth of a Thousand Illusions & & & \\
\hline U & Visit to family gardens and livestock areas & $\mathrm{x}$ & & $\mathrm{x}$ \\
\hline \multirow{15}{*}{ 岳 } & Participation in the Pampas & & $\mathrm{x}$ & $\mathrm{x}$ \\
\hline & Walk through the Jambiñán & & & $\mathrm{x}$ \\
\hline & Ritual of energizing & & & $\mathrm{x}$ \\
\hline & Visit to the ethnographic museum & & $x$ & \\
\hline & Use and treatment of medicinal plants & & & $x$ \\
\hline & Practice of rites dedicated to the gods of the Cañari people & & & $\mathrm{x}$ \\
\hline & We will observe historical sites & & & $\mathrm{x}$ \\
\hline & Craft sales & $\mathrm{x}$ & $\mathrm{x}$ & $\mathrm{x}$ \\
\hline & Flowering ceremonies and rituals & $\mathrm{x}$ & & \\
\hline & Kichwa teaching & & $x$ & \\
\hline & Visit to the Ingapirca Archaeological Complex. & & $x$ & \\
\hline & Visit of the Inca Trail & & $x$ & $\mathrm{x}$ \\
\hline & Visit to Labrsacarumi & & $\mathrm{x}$ & \\
\hline & Visit to the second oldest church in Ecuador & & $\mathrm{x}$ & \\
\hline & Practice of ancestral traditions and customs & $x$ & $x$ & $x$ \\
\hline
\end{tabular}




\subsection{Sumak Pacha}

The Community Tourism Network of the Cañari Sumak Pacha people, located in the Cañar canton, was constituted in 2011 with six communities of the Cañari people $[128,133,134]$ (Table 10). The tourist offer is based on the natural and cultural wealth of the province, mainly motivating the decentralization of the Ingapirca Archaeological Complex, towards the different cantons that surround it in order to appreciate the different attractions, customs, landscapes and traditions that each space has [133,135], and based on this, each community organizes its tourism products with different approaches, to attract both local, national and international visitors. By 2018, all the communities in this network were registered as CTCs, but currently none of them have renewed their registration within the National Tourist Cadastre of Establishment of MINTUR [109].

Table 10. Product lines and tourist activities for community entrepreneurship associated with Sumak Pacha.

\begin{tabular}{|c|c|c|c|c|c|c|c|}
\hline a & Activities & 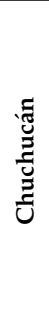 & 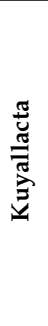 & 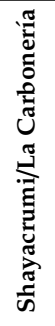 & 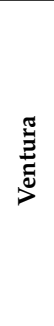 & 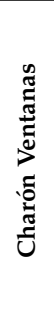 & $\stackrel{\widetilde{2}}{\frac{乛}{N}}$ \\
\hline \multirow{13}{*}{ 安 } & Guided walks & $\mathrm{x}$ & $\mathrm{x}$ & $\mathrm{x}$ & $\mathrm{x}$ & & $\mathrm{x}$ \\
\hline & Hiking different levels of difficulty & & & & & & $\mathrm{x}$ \\
\hline & Road cycling & & & & $\mathrm{x}$ & & \\
\hline & Horseback riding & & $\mathrm{x}$ & & $\mathrm{x}$ & & \\
\hline & Subtropical forest visits & & & & $\mathrm{x}$ & & \\
\hline & Camping & & & $\mathrm{x}$ & & & \\
\hline & Visit to natural viewpoint & $\mathrm{x}$ & & & & $\mathrm{x}$ & \\
\hline & Visit to Quinuales forest & $\mathrm{x}$ & & & & & \\
\hline & Visit to the Culebrillas Lagoon & & $\mathrm{x}$ & & & & \\
\hline & Visit to Tayta Charón & & & & & $\mathrm{x}$ & \\
\hline & Visit through primary forest & $\mathrm{x}$ & & $\mathrm{x}$ & & $\mathrm{x}$ & $\mathrm{x}$ \\
\hline & Stone Walls Trail & & $\mathrm{x}$ & & & & \\
\hline & Sport fishing & $\mathrm{x}$ & & & & & \\
\hline \multirow{7}{*}{ 牙 } & Participation in the Pampamesa & & $\mathrm{x}$ & & & & \\
\hline & Kichwa teaching & & $\mathrm{x}$ & & & & \\
\hline & Coexistence with the community & & $\mathrm{x}$ & & & & \\
\hline & Use and treatment of medicinal plants & & $\mathrm{x}$ & & & & \\
\hline & Visit to potato, barley and strawberry growing areas & & $\mathrm{x}$ & & & & \\
\hline & Wheat seed cleaning & & $\mathrm{x}$ & & & & \\
\hline & Cañari architecture appreciation & & $\mathrm{x}$ & & & & \\
\hline \multirow{7}{*}{ 它 } & Native music and dance & & $\mathrm{x}$ & & & & \\
\hline & Visit the Archaeological Museum of the Tambo City & & $\mathrm{x}$ & & & & \\
\hline & Walks along the old train tracks & & $\mathrm{x}$ & & & $\mathrm{x}$ & \\
\hline & Tasting of traditional gastronomy & & & & $\mathrm{x}$ & $\mathrm{x}$ & \\
\hline & Visit to the eco-tourist interpretation center & & & $\mathrm{x}$ & & & \\
\hline & Visit to the Zhuya Community Tourism Center & $\mathrm{x}$ & & & & & $\mathrm{x}$ \\
\hline & Visit to an old hacienda house & $\mathrm{x}$ & & & & & \\
\hline \multirow{2}{*}{$\stackrel{q}{4}$} & Visit to the Ingapirca Archaeological Complex & & $\mathrm{x}$ & & & $\mathrm{x}$ & \\
\hline & Visit to the Coyoctor Archaeological Complex & & $\mathrm{x}$ & & & & \\
\hline
\end{tabular}

LP-product line; EC-ecotourism, CT-cultural tourism; AR-archaeological, AT-adventure tourism, ET-ethnotourism; Source: Sarmiento [126]; Arévalo \& Romero [128]; Discover Ecuador [133]; Quintero [136]; Turismo Cañar [137]. 


\subsection{Saraguro Rikuy}

It is a subsidiary of the FEPTCE in the south of the country, which is responsible for promoting the sustainability perspective in community tourism in the canton of Saraguro, province of Loja. This organization takes those elements of the identity and territory of the Saraguro people as work elements, for developing short and long-stay package tours within the communities with ventures associated with the network [138]. The tourism operator Saraurku is constituted within the network, which promotes the ventures of the Namarín, Oñakapak, Gera, Ilincho and Lagunas communities [138,139], which are distributed in a $25 \mathrm{~km}$ radius from the cantonal head of Saraguro [40].

The organization offers meal, guide and accommodation services within the Achik Wasi Community Hostel. Regarding package tours, the operator provides a reservation interface that allows to design the package tour tailored to each client, highlighting that the company bases all its experiences on corporate social responsibility, under the criteria of coexistence and cultural exchange (Tables 11 and 12).

Table 11. Community enterprises associated with Saraguro Rikuy.

\begin{tabular}{ccc}
\hline Location & Entrepreneurship & Marketing Approach \\
\hline \multirow{3}{*}{ Loja } & Ilincho-Inty Wasi & Conserve the traditional indigenous culture \\
& Namarin & Conserve sacred sites \\
& Gera-Taski Wasi & Folklore, culture and nature \\
& Las Lagunas-Inka Wasi & Folklore, culture and nature \\
& Oñakapak-Virgin of Holy Water & Conserve the traditional indigenous culture \\
\hline Ond
\end{tabular}

Table 12. Product lines and tourist activities for community entrepreneurship associated with Saraguro Rikuy.

\begin{tabular}{|c|c|c|c|c|c|c|}
\hline$\tilde{a}$ & Activities & IInty Wasi & Namarin & Taski Wasi & Inka Wasi & Oñakapak \\
\hline \multirow{11}{*}{ U } & Guided walks & & $\mathrm{x}$ & & & \\
\hline & Excursions to the Inca Bath and the Mirador & & $x$ & & & \\
\hline & Excursions to the viewpoints and Pukara peak & & & $\mathrm{x}$ & & \\
\hline & Hikes to the Puglla hill & $x$ & & & & \\
\hline & Observation of endemic flora and fauna & $\mathrm{x}$ & $x$ & $x$ & & \\
\hline & Hiking routes through the Washapamba Community & & & & & \\
\hline & Protected Forest & $x$ & & & $\mathrm{x}$ & $\mathrm{x}$ \\
\hline & Visit of waterfall of the Virgen del Agua Santa & & & & & $\mathrm{x}$ \\
\hline & Visit of the Ismuchincha river & & & & & $x$ \\
\hline & Visit of the Cochapamba Lagoon & & & & & $x$ \\
\hline & Sport fishing & & & & & $\mathrm{x}$ \\
\hline \multirow{5}{*}{ 计 } & Visit the museum & & & $\mathrm{x}$ & & \\
\hline & Visit to Andean festivals & & & & $x$ & \\
\hline & Visit to the archaeological remains of the "Quinarki" & & & $\mathrm{x}$ & & \\
\hline & Sale of handicrafts & & & & $x$ & \\
\hline & Walks through the archaeological sites and the Inca terraces & & & & $\mathrm{x}$ & \\
\hline \multirow{4}{*}{ 它 } & Native music and dance & $\mathrm{x}$ & $\mathrm{x}$ & $\mathrm{x}$ & $\mathrm{x}$ & \\
\hline & Traditional food, such as Pinzhi, tortillas with colada & $\mathrm{x}$ & $\mathrm{x}$ & $\mathrm{x}$ & $x$ & \\
\hline & Craft workshops: in mullo, sheep wool and carpentry & & $x$ & $\mathrm{x}$ & $\mathrm{x}$ & \\
\hline & Extraction and tasting of the traditional Wajango drink & & & $\mathrm{x}$ & & \\
\hline$\underset{4}{U}$ & Organic farming practices (orchards) & & & & & $x$ \\
\hline \multirow{4}{*}{ 㫐 } & Flowering ceremonies and rituals & $\mathrm{x}$ & $\mathrm{x}$ & & $\mathrm{x}$ & $\mathrm{x}$ \\
\hline & Accommodation with families & $x$ & $\mathrm{x}$ & & & \\
\hline & Use of medicinal plants & & & & $x$ & \\
\hline & Kichwa teaching & & & & $\mathrm{x}$ & \\
\hline
\end{tabular}




\subsection{RICANCIE}

It was born in 1993, with the purpose of improving the living conditions of around 200 Kichwa families settled in the Alto Napo area, by opting for ecotourism. On one hand, to eliminate aggressive tourism that causes cultural erosion in the communities in the area, while, on the other hand, it seeks to restrict the devastating advance of the mining, lumber and oil industries present in the territory [140]. This organization is made up of ten communities: Capirona, Rio Blanco, Runa Wasi, Chuva Urku, Wasila Talag, Machakuyaku, Pacto Sumaco, Sinchipura, Alukus and Limoncocha [141]; in this way, all the work carried out by the organization focuses on the defense of the ancestral territory (natural and cultural resources) in which they are settled.

This organization promotes tours within the Amazon, which leave the city of Quito and are focused on knowing the natural and cultural diversity of the area, through different marketing approaches and product lines (Table 13). The tours have a minimum 2-day duration and a maximum 4-day duration in a single community and include accommodation, meals and guide facilities and services, as well as numerous activities per product line (Table 14). It must be specified that in case of requiring visits to several communities during the experience, this will depend on the organization of different types of tours to those traditionally commercialized.

Table 13. Community entrepreneurship associated with the Indigenous Network of Communities of the Alto Napo for Intercultural Coexistence and Ecotourism (RICANCIE).

\begin{tabular}{ccc}
\hline Location & Entrepreneurship & Marketing Approach \\
\hline & Pacto Sumaco & Adventure, birdwatching, nature and gastronomy \\
& Waysa Yaku de Alukus & Mountain, canyoning and spirituality \\
Limoncocha & Nature, alligators and rest \\
Napo & Machakuyaku & Cultural coexistence and spirituality \\
& Runa Wasi & Rest and relaxation \\
Río Blanco & Coexistence, health and shamanism \\
& Wasila Talag & Rest and coexistence \\
& Sinchipura & Adventure, conviviality and rafting \\
\hline
\end{tabular}

Only active entrepreneurships are described. Source: FEPTCE [40]; RICANCIE [141]; Infonapo [142].

All the communities offer the opportunity to carry out volunteer tourism experiences, whereby the visitor can learn about indigenous life in a Kichwa community in the Ecuadorian Amazon. During the visit, volunteers may collaborate in family activities, local production projects, health, education, etc.; as well as contributing their knowledge to strengthen community tourism. This product line is offered to groups of all ages, which can be secondary school or university students, religious groups, community service clubs and individuals.

\subsection{CORTUS}

The Sucumbíos Community Tourism Corporation, groups the communities of Shayari, Limoncocha, Siekoya Remolino, San Pablo de Katetsiayá, Aguas Negras and Atari [143] (Tables 15 and 16). The organization seeks to achieve the socioeconomic conditions required for an equitable life for the communities; in addition to working for the valuation and conservation of the environmental and cultural heritage of the different indigenous nationalities existing in the communities [144]. It must be specified that the population associated with the ventures identifies itself as being $60 \%$ part of the Kwicha Nationality, 34\% of the Secoya Nationality (Siekopaii) and $0.5 \%$ as members of the Shuar Nationality; while $6 \%$ define themselves as mestizo and 3.5\% as part of other nationalities or peoples [145]. 
Table 14. Product lines and tourist activities for community entrepreneurship associated with RICANCIE.

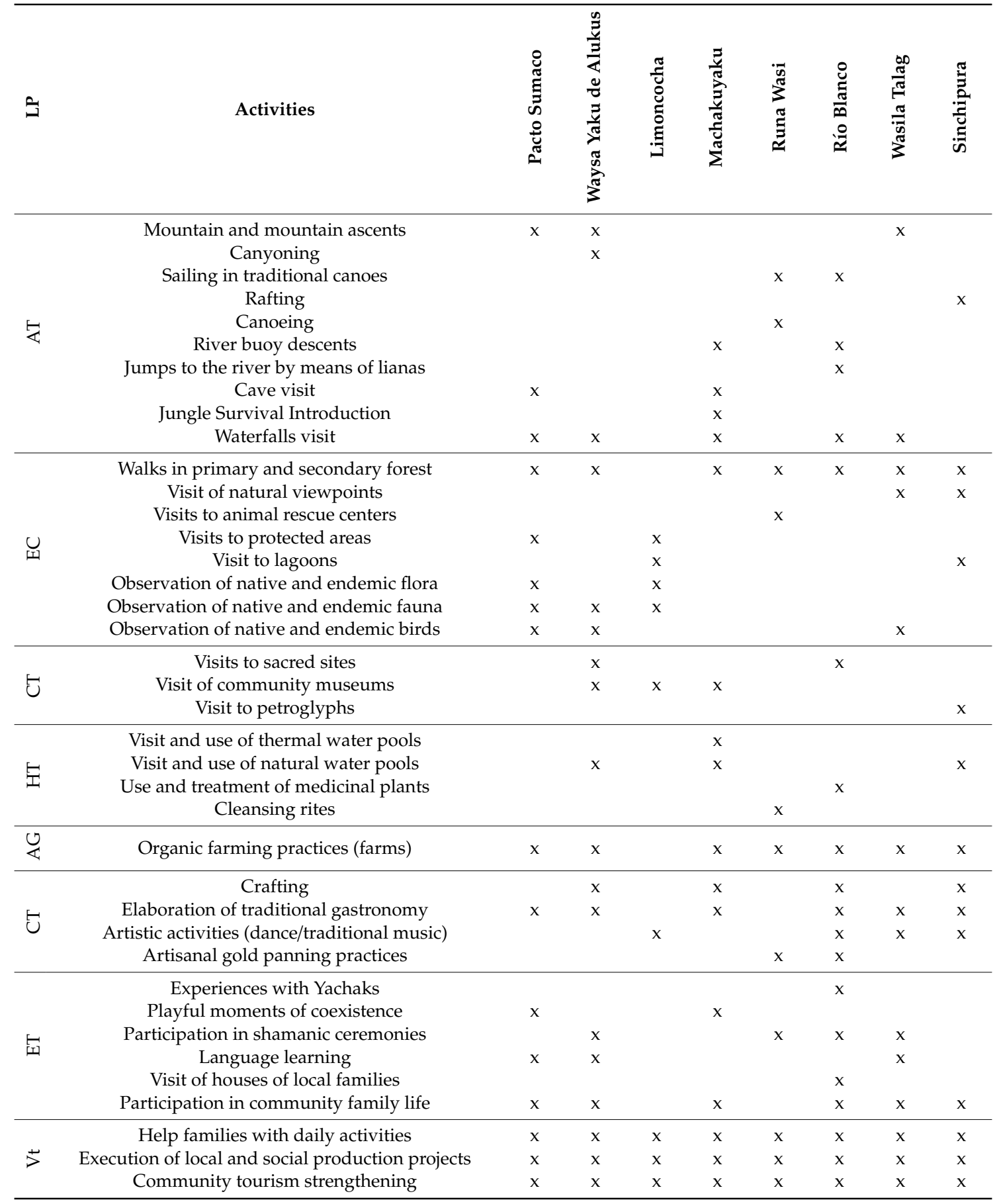

LP—product line; AT-adventure tourism; EC-ecotourism; TC—cultural tourism; HT-health tourism; AG—agrotourism; CT—creative tourism; ET—ethnotourism; VT—volunteer tourism. Only active entrepreneurships are described. Source: FEPTCE [40]; RICANCIE [141]; Infonapo [142]. 
Table 15. Community ventures associated with CORTUS.

\begin{tabular}{|c|c|c|}
\hline Location & Entrepreneurship & Marketing Approach \\
\hline \multirow[t]{2}{*}{ Sucumbios } & Siekoya Remolino & $\begin{array}{l}\text { Conservation and exchange of the living culture of the } \\
\text { Siekopaii nationality. }\end{array}$ \\
\hline & Shayari & $\begin{array}{l}\text { The Amazon corner that preserves the ecological and } \\
\text { cultural diversity of the Amazon Kichwa people. }\end{array}$ \\
\hline
\end{tabular}

Table 16. Product lines and tourist activities for community entrepreneurship associated with CORTUS.

\begin{tabular}{|c|c|c|c|}
\hline$\vec{a}$ & Activities & $\begin{array}{c}\text { Siekoya } \\
\text { Remolino }\end{array}$ & Shayari \\
\hline \multirow{10}{*}{ 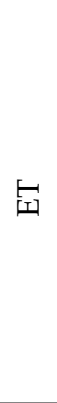 } & Hiking in tropical forest & $x$ & \\
\hline & Hiking in tropical rainforest & & $x$ \\
\hline & Visit to botanical garden & $x$ & \\
\hline & Observation of native and endemic flora & & $x$ \\
\hline & Observation of native and endemic fauna & & $x$ \\
\hline & Observation of native and endemic birds & $x$ & \\
\hline & Visit to married Ayahuasca & & $x$ \\
\hline & Visit to Animal Rescue Centers & & $x$ \\
\hline & Visit to Zoo-hatcheries & & $x$ \\
\hline & Canoeing & & $\mathrm{x}$ \\
\hline \multirow{2}{*}{$\ddot{U}$} & Visit to the Cultural Interpretation Center & $x$ & \\
\hline & Exhibition and sale of handicrafts & $\mathrm{x}$ & $\mathrm{x}$ \\
\hline \multirow{2}{*}{ 至 } & Use of natural pools & & $x$ \\
\hline & Learning of medicinal plants & & $\mathrm{x}$ \\
\hline \multirow{3}{*}{ 计 } & Demonstration of the elaboration of gastronomy & $x$ & $x$ \\
\hline & food with all the culinary wealth & $\mathrm{x}$ & $\mathrm{x}$ \\
\hline & $\begin{array}{l}\text { Painting, sculpture and crafts workshops with } \\
\text { materials from the area }\end{array}$ & $x$ & $x$ \\
\hline 島 & Cultural coexistence from community activities & $x$ & $x$ \\
\hline
\end{tabular}

PL-product line, EC-ecotourism, TC-cultural tourism, HT-health tourism, CT-creative tourism; ET-ethnotourism. Only active entrepreneurships are described. Suorce: Newspaper El Universo [146]; CTC Shayari [147]; La Geoguía Project [148].

Currently, of the seven ventures associated with CORTUS, only two of them are active, which are Siekoya Remolino and Shayari. The latter is classified as a consolidated venture due to having the CTC registration by MINTUR for the year 2020 .

\subsection{Network of Community Tourist Centers of the Arajuno Canton (RCTC-CA)}

It begins in 2007, with six initiatives identified as Community Tourism Operations (OTC), to which seven more communities would be added in the following year. All these ventures have been classified in the process of development and consolidation of the community tourism offer, giving an approximate total of 3660 direct beneficiaries [149]. Thus, the network is made up of two initiatives of communities of the Shuar nationality and 11 of the Kichwa nationality, of which six were recognized as legal of their community tourism centers by the FEPTCE for 2010 [150] (Tables 17 and 18).

It must be highlighted that $40 \%$ of the Yasuní National Park is located within the Arajuno canton, an ecosystem that has provided this space with countless natural and cultural attractions, making it a paradise at its best. The ventures associated with this network show coexistence with the Kichwa and Shuar nationalities [151], which seek to improve the population's cultural, economic and spiritual level of life through the exchange of worldviews of these nationalities [152]. 
Table 17. Community ventures associated with the Network of Community Tourist Centers of the Arajuno Canton (RCTC-CA).

\begin{tabular}{ccc}
\hline Location & Entrepreneurship & Marketing Approach \\
\hline \multirow{2}{*}{ Pastaza } & Akamkaw of Saint Virgil & ecotourism, ethnotourism and cultural tourism \\
& CEPLOA & Health tourism, ecotourism and adventure tourism \\
\hline
\end{tabular}

Only active entrepreneurships are described. Source: Reyes \& Ortega [149]; PROCASUR [150]; Yánez [152].

Table 18. Líneas de producto y actividades turísticas por emprendimiento comunitario asociado a la RCTC-CA.

\begin{tabular}{|c|c|c|c|}
\hline$\vec{a}$ & Activities & Akamkaw of Saint Virgil & Ceploa \\
\hline \multirow{7}{*}{$\bigcup_{\text {U工工 }}^{u}$} & Jungle walks on ecological trails & $\mathrm{x}$ & \\
\hline & Night walks & $x$ & $x$ \\
\hline & Observation of flora and fauna & $\mathrm{x}$ & $\mathrm{x}$ \\
\hline & Visit to the waterfalls & $x$ & \\
\hline & Bath in the crystal clear waters of the Curaray River & $x$ & \\
\hline & Bird watching & $\mathrm{x}$ & $\mathrm{x}$ \\
\hline & Visit to parrot saladero & & $\mathrm{x}$ \\
\hline 昰 & Practice of survival techniques of the Kichwa people & $\mathrm{x}$ & \\
\hline \multirow{4}{*}{ 牙 } & Welcome ceremony & $\mathrm{x}$ & \\
\hline & Kichwa Cultural Exchange & $\mathrm{x}$ & $\mathrm{x}$ \\
\hline & Toma de la Guayusa & $x$ & \\
\hline & Narrative of ancient stories and legends & $x$ & \\
\hline \multirow{4}{*}{$\ddot{U}$} & Crafting & $\mathrm{x}$ & \\
\hline & Music and dance performances & $x$ & $\mathrm{x}$ \\
\hline & Craft Exhibition & & $x$ \\
\hline & Gastronomy typical and a la carte dishes & & $x$ \\
\hline \multirow{2}{*}{ 岳 } & Recognition of medicinal plants & & $x$ \\
\hline & Practice on uses of the flora of the sector. & $x$ & \\
\hline
\end{tabular}

Among the strategies used by the RCTC-CA for disseminating the ventures, there is a link with the Yachak Tourist Route, although the effects achieved have not been those expected by the network [152].

After analyzing all the provincial and cantonal networks linked to the FEPTCE, we proceed to examine the tourist offer of the ventures: $16 \%$ of these focus on providing a single service, establishing that $10 \%$ are dedicated to meals mainly within the coastal region; while $6 \%$ are only dedicated to accommodation, which correspond to ventures associated with Runa Tupari.

On the other hand, $71 \%$ of the enterprises provide various services within their offer, $45 \%$ offer a combination of meals, accommodation and a guide service; followed by $17 \%$ that offer Meals and accommodation; $8 \%$ provide meals and a guide service and only one enterprise offers all services including meals, accommodation, guide services and transportation. Finally, $11(13 \%)$ enterprises that offer exclusively tourist activities are included in the packages organized by the Runa Tupari operator $[149,150,152,153]$.

\section{Conclusions}

The focus of this research was exploratory, descriptive and analytical, allowing us to observe that Ecuador is committed to sustainable development, tending to community tourism as a means for social development, the sustainable management of its territories, the revitalization of its cultures and the revitalization of the community economy, in order to contribute to the achievement of the Sustainable Development Goals of the UN 2030 Agenda. This type of tourism has the capacity to contribute to the achievement of objective (1) eradicate poverty, objective (3) improvement of the quality of life of its 
most vulnerable communities; objective (5) and (10) contribute to gender equality and the reduction of inequalities among the population; objective (6) and (12) takes up the use of production systems that conserve resources and allow responsible consumption through the application of ancestral knowledge; as well as the achievement of objectives (13), (14) and (15) due to the actions of protection of the cultural and natural heritage of the territories, a fact that has allowed to expand the protection zones and strengthen their conservation.

Community tourism in Ecuador has gone through several definition processes, where the fundamental key for a correct conceptualization of this form of tourism is the community perspective and a network approach to its development and governance. Vision in which the community produces the tourist activity as a cultural meeting and refuses to be the object of folkloric attraction. FEPTCE is the organization formed by the community tourism centers to defend and protect the interests of the community and has been a key element for the consolidation of this perspective within the tourism sector of Ecuador. FEPTCE has a presence in all the regions of continental Ecuador, finding itself day-by-day in a demanding process of reactivation of the territories that had suspended their activities due to numerous social situations, environmental or economic; the neuralgic element of their work is not the generation of economic benefits, but to go further, towards the generation of positive impacts on natural and cultural environments, and thereby influence the good living of all communities.

The FEPTCE allowed for the integration of a wide diversity of peoples and nationalities, resulting in the existence of 121 community ventures within the continental territory, from 2002 to 2020, with 83 currently active, of which 18 initiatives are consolidated and registered as Community Tourist Centers-CTC as they are legally constituted. These CTCs are part of the 39 existing in the country. The community initiatives covered by the FEPTCE have been created following a network approach; at regional (5 networks) and provincial or cantonal level (9 networks); Community Tourism Muisne, Sumak Pacha, Saraguru Rikuy, Runa Tupari, CORTUS, RICANCIE, CORDTUCH, Pakariñan and RCTC-CA.

The consolidation of these ventures over time has been very difficult because the quality standards applied by MINTUR, together with the deficiency of a basic infrastructure that Ecuador has within rural areas, has led to many of these ventures not being recognized as CTC. In this context, the question arises, what benefits do these ventures obtain from being recognized as CTC? The answer so far is that the only benefit of the perceived recognition is being part of the country's official tourist offer, an action that does not contribute to a solution to these territories' needs, since it does not affect an increase in tourism flows.

At this point it can be specified that beyond the official recognition as a CTC of tourist ventures, the FEPTCE has generated a management model, which takes community tourism to another level, passes from an economic vision to a social vision, which in certain The measure materializes the philosophical postulates, socialized and disseminated by the UNWTO, UNESCO, PUND, UN, among other international entities, allowing the elements of sustainability and social responsibility with the territories to gain strength and begin to become a tangible reality.

With regard to the tourist activities offered by the CBT initiatives, the analysis carried out allows us to observe that they offer together in each of the networks created a significant number of activities related to cultural and creative tourism, ecotourism, health tourism, adventure archeology, ethnotourism, experiential tourism and voluntary tourism. Among the main marketing lines that these ventures are working with are ecotourism for the use of natural resources and increased environmental awareness of the visitor, as well as ethno-tourism for the use of cultural wealth and coexistence of the cultures of the territories.

In Latin America, it opted for the development of the CBT through the network approach and currently has the widest and most developed offer of this type of tourism compared to the other two areas where the BCT is concentrated, Southeast Asia (Laos, Cambodia and Thailand) and Africa (it is very underdeveloped). Thus, numerous networks arise both nationally and regionally, such as the Community Tourism Network in Latin America, REDTURS (Costa Rica), TUSOCO (Bolivia), TUCUM 
(Brazil), among others. These networks are becoming an essential support for the development and commercialization of the CTB. This case study shows that in Ecuador the network approach as the first step in the development of the CBT worked taking into account the number of networks created and initiatives launched. At this point it is necessary to mention that Ecuador is one of the most developed and recognized countries in the exercise of community tourism.

This organization and management model has allowed the FEPTCE to distinguish itself from the other seven national federations in Latin America (Indigenous Tourism Network of Mexico, National Federation of Community Tourism of Guatemala, Nicaraguan Network of Community Rural Tourism, Costa Rican Tourism Association Rural Community, Network of Rural Community Tourism of Costa Rica, Bolivian Network of Community Solidarity Tourism and Brazilian Network of Community Solidarity Tourism), due to the fact that its postulates of (a) management and defense of the territories inhabited by the peoples; (b) generation of benefits beyond the economic; (3) revitalization of culture; and (4) socio-organizational strengthening, they have made it the national representative of the community sector, giving it voice and vote as a member of the Advisory Council of the Ministry of Tourism. In this way, the community sector has become the third key actor in the country's public policy of tourism, being recognized within the tourism law of Ecuador.

Therefore, the development of the CBT must be approached from a network approach in which rural communities, peasants and indigenous peoples (indigenous, mestizo, Afro-descendant, etc.), administrations, the private sector, civil society, NGOs and tourist destinations, which should be joined by academic institutions providing solid data obtained through research that helps tourism development. However, for its continuity, it is necessary to implement actions that allow communities to acquire the necessary skills for the management of their activities/businesses, such as managerial, business and marketing skills, as well as improving infrastructures, biosecurity conditions, connectivity and land and air communication, thereby promoting international demand. As long as the communities do not acquire these skills, their continuity goes through hiring specialized external administrators.

Author Contributions: All authors contributed equally to this work. Conceptualization, Methodology, Formal Analysis, Investigation, Writing-Original, Draft Preparation and Writing-Review and Editing, C.P.M.-E., M.d.l.C.d.R.-R., P.N.-V., J.Á.-G. All authors have read and agreed to the published version of the manuscript.

Funding: This research received no external funding.

Conflicts of Interest: The authors declare no conflicts of interest.

\section{References}

1. Guzmán, T.J.L.G.; Cañizares, S.M.S. Turismo comunitario y generación de riqueza en países en vías de desarrollo. Un estudio de caso en El Salvador/A case study in El Salvador. REVESCO. Rev. Estudios Coop. 2009, 99, 85-103.

2. Agüera, F.O. El turismo comunitario como herramienta para el desarrollo sostenible de destinos subdesarrollados/Community tourism as a tool for the sustainable development of underdeveloped destinations. Nómadas Crit. J. Soc. Juridical Sci. 2013, 38, 79-91.

3. Chernela, J. Barriers Natural and Unnatural: Islamiento as a Central Metaphor in Kuna Ecotourism. Bull. Lat. Am. Res. 2011, 30, 35-49. [CrossRef]

4. WWF International. Guidelines for Community-Based Ecotourism Development WWF International; WWF International: London, UK, 2001.

5. WTO-World Tourism Organization. Poverty Alleviation Through Tourism: A Compilation of Good Practices; World Tourism Organization: Madrid, Spain, 2006.

6. World Tourism Organization. World Tourism in 2002: Better Than Expected. 2002. Available online: http://www.world-tourism.org/newsroom/Releases/archives.htm (accessed on 1 August 2020).

7. Hiwasaki, L. Community-based tourism: A pathway to sustainability for Japan's protected areas. Soc. Nat. Resour. 2006, 19, 675-692. [CrossRef] 
8. Ruiz, E.; Hernández, M.; Coca, A.; Cantero, P.; Del Campo, A. Community tourism in Ecuador. Understanding community-based tourism from the community/Turismo comunitario en Ecuador. Comprendiendo el community-based tourism desde la comunidad. PASOS Rev. Turismo Patrimonio Cult. 2008, 6, 399-418. [CrossRef]

9. CODESPA Foundation. Programa RUTAS: La Apuesta por un Turismo Inclusivo en Latinoamérica. 2013. Available online: http://publicaciones.caf.com/media/41737/modelo-rutasturismo-rural-comunitario.pdf (accessed on 1 August 2020).

10. Stabler, M.J. Tourism E Sustainability: Principles to Practice; Cab International: New York, NY, USA, 1997.

11. Hall, C.M.; Lew, A.A. Sustainable Tourism: Geographical Perspectives; Addison Wesley Longman Ltd.: New York, NY, USA, 1998; pp. 1-24.

12. Bramwell, B.; Lane, B. Sustainable tourism: An evolving global approach. J. Sustain. Tour. 1993, 1, 1-5. [CrossRef]

13. World Commission on Environment \& Development (WCED). Our Common Future; Oxford University Press: Oxford, UK, 1987.

14. Cawley, M.; Marsat, J.B.; Gillmor, D.A. Promoting integrated rural tourism: Comparative perspectives on institutional networking in France and Ireland. Tour. Geogr. 2007, 9, 405-420. [CrossRef]

15. Gretzel, U.; Fesenmaier, D.R. Implementing a knowledge-based tourism marketing information system: The Illinois tourism network. Info. Technol. Tour. 2003, 6, 245-255. [CrossRef]

16. Hall, C.M. Tourism: Rethinking the Social Science of Mobility; Pearson Education: Harlow, UK, 2005.

17. Zach, F.; Racherla, P. Assessing the value of collaborations in tourism networks: A case study of Elkhart County, Indiana. J. Travel Tour. Mark. 2011, 28, 97-110. [CrossRef]

18. Choi, H.C.; Sirakaya, E. Sustainability indicators for managing community tourism. Tour. Manag. 2006, 27, 1274-1289. [CrossRef]

19. Nyaupane, G.P.; Morais, D.B.; Dowler, L. The role of community involvement and number/type of visitors on tourism impacts: A controlled comparison of Annapurna, Nepal and Northwest Yunnan, China. Tour. Manag. 2006, 27, 1373-1385. [CrossRef]

20. Okazaki, E. A community-based tourism model: Its conception and use. J. Sustain. Tour. 2008, 16, 511-529. [CrossRef]

21. Dyer, P.; Aberdeen, L.; Schuler, S. Tourism impacts on an Australian indigenous community: A Djabugay case study. Tour. Manag. 2003, 24, 83-95. [CrossRef]

22. Lepp, A. Residents' attitudes towards tourism in Bigodi village, Uganda. Tour. Manag. 2007, 28, 876-885. [CrossRef]

23. Manyara, G.; Jones, E. Community-based tourism enterprises development in Kenya: An exploration of their potential as avenues of poverty reduction. J. Sustain. Tour. 2007, 15, 628-644. [CrossRef]

24. Kibicho, W. Community-base tourism: A factor-cluster segmentation approach. J. Sustain. Tour. 2008, 16, 211-231. [CrossRef]

25. Guerreiro Marcon, E.M. O turismo como agente de desenvolvimento social e a comunidade Guarani nas "Ruínas Jesuíticas de Sao Miguel das Missoes". Rev. Turismo Patrimonio Cult. 2007, 5, 343-352. [CrossRef]

26. Juárez, J.P.; Ramírez, B. El turismo rural como complemento al desarrollo territorial rural en zonas indígenas de México. Scripta Nova Rev. Electr. Geogr. Ciencias Soc. 2007, 11, 236.

27. Zorn, E.; Farthing, L.C. Communitarian tourism. Hosts and mediators in Peru. Ann. Tour. Res. 2007, 34, 673-689. [CrossRef]

28. Ballesteros, E.R.; Carrión, D.S. Turismo Comunitario en Ecuador: Desarrollo y Sostenibilidad Social; Editorial Abya Yala: Quito, Ecuador, 2007.

29. De la Torre, S. Turismo comunitario ¿ otro sueño inalcanzable? Polémika 2010, 2, 597-614.

30. Prieto, M. Espacios en Disputa: El Turismo en Ecuador, 1st ed.; Flacso, E., Ed.; Flacso-Sede Ecuador: Quito, Ecuador, 2011; p. 232.

31. Reyes, J.E.; Ballesteros, E.R. Resiliencia Socioecológica: Aportaciones y retos desde la Antropología. Rev. Antropol. Soc. 2011, 20, 109-135.

32. Roux, F. Ecuadorian Community Tourism, Environmental Conservation and Defense of the Territories/Turismo Comunitario Ecuatoriano, Conservación Ambiental y Defensa de Los Territorios; Federación Plurinacional de Turismo Comunitario del Ecuador (FEPTCE): Quito, Ecuador, 2013.

33. Álvarez-García, J.; Durán-Sánchez, A.; Río-Rama, D.; De la Cruz, M. Scientific coverage in community-based tourism: Sustainable tourism and strategy for social development. Sustainability 2018, 10, 1158. [CrossRef] 
34. Guamán, M.A. Community Tourism: Scope, Limitations and Development Proposal in the Province of Chimborazo/El Turismo Comunitario: Alcances, Limitaciones y Propuesta de Desarrollo en la Provincia de Chimborazo; Escuela Superior Politécnica de Chimborazo: Riobamba, Ecuador, 2016.

35. Moscardo, G. Community capacity building: An emerging challenge for tourism development. In Building Community Capacity for Tourism Development; CABI: Oxford, UK, 2008; pp. 1-15.

36. Ruiz-Ballesteros, E.; Hernández-Ramírez, M. Tourism that empowers? Commodification and appropriation in Ecuador's turismo comunitario. Crit. Anthropol. 2010, 30, 201-229. [CrossRef]

37. Rocharungsat, P. Community-based tourism in Asia. In Building Community Capacity for Tourism Development; Moscardo, G., Ed.; CABI: Wallingford, UK, 2008; pp. 60-74.

38. Brohman, J. New Directions in Tourism for the Third World. Ann. Tour. Res. 1996, 23, 48-70. [CrossRef]

39. Goodwin, H.; Santilli, R. CommunityBased Tourism: A Success? ICRT Occas. Pap. 2009, 11, 37.

40. FEPTCE. Federación Plurinacional de Turismo Comunitario del Ecuador. 2007. Available online: https: //www.facebook.com/TurismoComunitarioEc/ (accessed on 7 May 2020).

41. Mitchell, R.E.; Reid, D.G. Community integration: Island tourism in Peru. Ann. Tour. Res. 2001, $28,113-139$. [CrossRef]

42. Ramsa-Yaman, A.; Mohd, A. Community-based ecotourism: A new proposition for sustainable development and environmental conservation in Malaysia. J. Appl. Sci. 2004, 4, 583-589.

43. Jones, S. Community-based ecotourism: The significance of social capital. Ann. Tour. Res. 2005, 32, 303-324. [CrossRef]

44. Kontogeorgopoulos, N. Community-based ecotourism in Phuket and Ao Phangnga, Thailand: Partial victories and bittersweet remedies. J. Sustain. Tour. 2005, 13, 4-23. [CrossRef]

45. Harrison, D. Pro-poor Tourism: A critique. Third World Q. 2008, 29, 851-868. [CrossRef]

46. Simpson, M.C. Community Benefit Tourism Initiatives-A conceptual oxymoron? Tour. Manag. 2008, 29, 1-18. [CrossRef]

47. Harrison, D.; Schipani, S. Lao Tourism and Poverty Alleviation: Community-Based Tourism and the Private Sector. Curr. Issues Tour. 2007, 10, 194-230. [CrossRef]

48. Cabanilla, E. Turismo comunitario en América Latina, un concepto en construcción. Siembra 2018, 5, $121-131$. [CrossRef]

49. Altimira, R.; Muñoz, X. El turismo como motor de crecimiento económico. Anuario Jurídico Económico Escurialense 2007, 40, 677-710.

50. Bauman, Z. Community: Seeking Safety in an Insecure World; John Wiley \& Sons: London, UK, 2013.

51. Belsky, J.M. Misrepresenting Communities: The Politics of Community-Based Rural Ecotourism in Gales Point Manatee, Belize1. Rural Soc. 1999, 64, 641-666. [CrossRef]

52. Temple, D. The Elementary Structures of Reciprocity: Milestones for a Qualitative Economy in the Third Millennium/Las Estructuras Elementales de la Reciprocidad: Jalones para Una Economía Cualitativa en el Tercer Milenio; Plural Editores: La Paz, Bolivia, 2003.

53. Fernández, M.T. Turismo comunitario y empresas de base comunitaria turísticas: ¿estamos hablando de lo mismo? El Periplo Sustentable 2011, 20, 31-74.

54. Guerrero, P. Ethnographic Guide/Guía Etnográfica; Abya Yala: Quito, Ecuador, 2002.

55. Pastor, V.; Casa, C.; Soler, A. Rural development through community tourism. Colca valley and canyon analysis/Desarrollo rural a través del turismo comunitario. Análisis del valle y cañón de Colca. Gestión Turística 2011, 15, 1-20. [CrossRef]

56. Domet, R. The Alps are dying. World Press Rev. 1991, 38, 54-55.

57. Mowforth, A.; Munt, I. Tourism \& Sustainability: New Tourism in the Third World; Routledge: London, UK, 1998.

58. Healy, R.G. Tourist merchandise' as a means of generating local benefits from ecotourism. J. Sustain. Tour. 1994, 2, 137-151. [CrossRef]

59. Hall, C.M.; McArthur, S. Integrated Heritage Management: Principles \& Practice; The Stationery Office: London, UK, 1998.

60. Richard, G.; Hall, D. Tourism \& Sustainable Community Development; Routledge: New York, NY, USA, 2000.

61. PROCASUR. Community Tourism Management-Ecuador/Manejo del Turismo Comunitario-Ecuador; PROCASUR, FIDA: Quito, Ecuador, 2015.

62. Pretty, J. The many interpretations of participation. Focus 1995, 16, 4-5. 
63. Jamal, T.B.; Getz, D. Collaboration theory and community tourism planning. Ann. Tour. Res. 1995, 22, 186-204. [CrossRef]

64. Scott, N.; Baggio, R.; Cooper, C. Network Analysis and Tourism: From Theory to Practice. In Network Analysis and Tourism; Channel View Publications: Clevedon, UK, 2008.

65. Beaumont, N.; Dredge, D. Local tourism governance: A comparison of three network approaches. J. Sustain. Tour. 2010, 18, 7-28. [CrossRef]

66. Reed, M.G. Power relations and community-based tourism planning. Ann. Tour. Res. 1997, $24,566-591$. [CrossRef]

67. Tremblay, P. An evolutionary interpretation of the role of collaborative partnerships in sustainable tourism. In Tourism Collaboration and Partnerships: Politics, Practice and Sustainability; Bramwell, B., Lane, B., Eds.; Channel View Publications: Clevedon, UK, 2000; pp. 314-332.

68. Bramwell, B.; Lane, B. Collaboration and partnerships in tourism planning. In Tourism Collaboration and Partnerships: Politics, Practice and Sustainability; Channel View Publications: Clevedon, UK, 2000; pp. 1-19.

69. Lynch, P.A. Networking in the homestay sector. Serv. Ind. J. 2000, 20, 95-116. [CrossRef]

70. Johns, N.; Lynch, P.A.; Morrison, A.J. International tourism networks. Int. J. Contemp. Hosp. Manag. 2004, 16, 197-202.

71. Augustyn, M.M.; Knowles, T. Performance of tourism partnerships: A focus on York. Tour. Manag. 2000, 21, 341-351. [CrossRef]

72. Halme, M. Learning for sustainable development in tourism networks. Bus. Strategy Environ. 2000, 10, 100-114. [CrossRef]

73. Alison, J.M. Marketing Strategic Alliances: The Small Hotel Firm. Int. J. Contemp. Hosp. Manag. 1994, 6, $25-30$.

74. Casas Jurado, A.C.; Soler Domingo, A.; Pastor, V.J. Community tourism as instrument of eradication of poverty: Potential for its development in Cuzco (Perú). Cuadernos Turismo 2012, 30, 91-299.

75. Dodds, R.; Ali, A.; Galaski, K. Mobilizing knowledge: Determining key elements for success and pitfalls in developing community-based tourism. Curr. Issues Tour. 2018, 21, 1547-1568. [CrossRef]

76. Trejos, B.; Matarrita-Cascante, D. Theoretical approximations to community-based tourism: Case studies from Costa Rica. E-Rev. Tour. Res. 2010, 8, 157-178.

77. Mayaka, M.; Croy, W.G.; Cox, J.W. Participation as motif in community-based tourism: A practice perspective. J. Sustain. Tour. 2018, 26, 416-432. [CrossRef]

78. Boley, B.B.; Maruyama, N.; Woosnam, K. Measuring empowerment in an eastern context: Findings from Japan. Tour. Manag. 2015, 50, 112-122. [CrossRef]

79. Timothy, D.J.; White, K. Community-based ecotourism development ion the periphery of Belize. Curr. Issues Tour. 1999, 2, 226-243. [CrossRef]

80. Mbaiwa, J.E. Community-based tourism and the marginalized communities in Botswana: The case of the Basarna in Okavango Delta. In Indigenous Tourism: The Commodification and Management of Culture; Ryan, C., Aicken, M., Eds.; Elsevier: London, UK, 2005; pp. 87-109.

81. Wyllie, R.W. Hana revisited: Development and controversy in a Hawaiian tourism community. Tour. Manag. 1998, 19, 171-178. [CrossRef]

82. Ying, T.; Zhou, Y. Community, governments and external capitals in China's rural cultural tourism: A comparative study of two adjacent villages. Tour. Manag. 2008, 28, 96-107. [CrossRef]

83. Iorio, M.; Wall, G. Behind the masks: Tourism and community in Sardinia. Tour. Manag. 2012, 33, $1440-1449$. [CrossRef]

84. Alaeddinoglu, F.; Can, A.S. Identification and classification of nature-based tourism resources: Western Lake Van basin, Turkey. Proc. Soc. Behav. Sci. 2012, 19, 198-207. [CrossRef]

85. Ishii, K. The impact of ethnic tourism on hill tribes in Thailand. Ann. Tour. Res. 2012, 39, 290-310. [CrossRef]

86. Iorio, M.; Corsale, A. Rural tourism and livelihood strategies in Romania. J. Rural Stud. 2010, 26, 152-162. [CrossRef]

87. Lapeyre, R. Community-based tourism as a sustainable solution to maximise impacts locally? The Tsiseb Conservancy case, Namibia. Dev. S. Afr. 2010, 27, 757-772. [CrossRef]

88. Patterson, T.; Gulden, T.; Cousins, K.; Kraev, E. Integrating environmental, social and economic systems: A dynamic model of tourism in Dominica. Ecol. Model. 2004, 175, 121-136. [CrossRef] 
89. Nelson, F.; Foley, C.; Foley, L.S.; Leposo, A.; Loure, E.; Peterson, D.; Peterson, M.; Peterson, T.; Sachedina, H.; Williams, A. Payments for Ecosystem Services as a Framework for Community-Based Conservation in Northern Tanzania. Conserv. Biol. 2010, 24, 78-85. [CrossRef] [PubMed]

90. Stewart, E.J.; Draper, D. Reporting back research findings: A case study of community-based tourism research in northern Canada. J. Ecotour. 2009, 8, 128-143. [CrossRef]

91. López-Guzmán, T.; Borges, O.; Cerezo, J.M. Community-based tourism and local socio-economic development: A case study in Cape Verde. Afr. J. Bus. Manag. 2011, 5, 1608-1617.

92. Reimer, J.K.; Walter, P. How do you know it when you see it? Community-based ecotourism in the Cardamom Mountains of southwestern Cambodia. Tour. Manag. 2013, 34, 122-132. [CrossRef]

93. Chakravarty, S.; Irazábal, C. Golden geese or white elephants? The paradoxes of world heritage sites and community-based tourism development in Agra, India. Commun. Develop. 2011, 42, 359-376. [CrossRef]

94. Giampiccoli, A.; Kalis, J.H. Tourism, Food, and Culture: Community-Based Tourism, Local Food, and Community Development in M pondoland. Cult. Agricult. Food Environ. 2012, 34, 101-123. [CrossRef]

95. Farrelly, T.A. Indigenous and democratic decision-making: Issues from community-based ecotourism in the Boumā National Heritage Park, Fiji. J. Sustain. Tour. 2011, 19, 817-835. [CrossRef]

96. Sommerville, M.; Jones, J.P.; Rahajaharison, M.; Milner-Gulland, E.J. The role of fairness and benefit distribution in community-based Payment for Environmental Services interventions: A case study from Menabe, Madagascar. Ecol. Econ. 2010, 69, 1262-1271. [CrossRef]

97. Lee, T.H.; Jan, F.H. Can community-based tourism contribute to sustainable development? Evidence from residents' perceptions of the sustainability. Tour. Manag. 2019, 70, 368-380. [CrossRef]

98. Koster, R.L.; Main, D. Community-Based Tourism as an Antidote for Being Part of the Boring Bits in Between: A Case Study of Terrace Bay, Ontario, Canada. In Perspectives on Rural Tourism Geographies; Springer: Cham, Germany, 2019; pp. 197-220.

99. Carpentier, J. Community Tourism and Its New Actors: The Case of Oil Companies in the Ecuadorian Amazon/El Turismo Comunitario y Sus Nuevos Actores: El Caso de Las Petroleras en la Amazonia Ecuatoriana. In Amazon, Travelers, Tourists and Indigenous Populations/Amazonía, Viajeros, Turistas y Poblaciones Indígenas; del Rio, J.M.V., Ed.; pp. 293-328. Pasos. 2012. Available online: https: //hal-univ-paris10.archives-ouvertes.fr/hal-01632040 (accessed on 7 May 2020).

100. Tourism Law/Ley de Turismo. Registro Oficial Suplemento No. 733, 27 de Diciembre de 2002. Ecuador. 2002. Available online: https://www.turismo.gob.ec/wp-content/uploads/2019/11/LEY-DE-TURISMO.pdf (accessed on 17 March 2020).

101. FEPTCE. The FEPTCE Declares Itself in Civil Disobedience/La FEPTCE se Declara en Desobediencia Civil; CEDENMA, Imprenta Mariscal: Quito, Ecuador, 2006.

102. Cabanilla, E.; Garrido, C. El Turismo Comunitario en el Ecuador: Evolución, Problemática y Desafios; UIDE-Universidad Internacional del Ecuador: Quito, Ecuador, 2018.

103. Plurinational Federation of Community Tourism of Ecuador. Turismo Comunitario-Información/Turismo Comunitario-Información. 2020. Available online: https://www.facebook.com/pg/TurismoComunitarioEc/ about/?ref=page_internal (accessed on 7 May 2020).

104. Declaration of Otavalo. 2001. Available online: https://www.eluniverso.com/2010/06/26/1/1355/documentodeclaracion-otavalo.html (accessed on 7 March 2020).

105. Maldonado, C. Tourism and Indigenous Communities: Impacts, Guidelines for Self-Evaluation and Codes of Conduct/Turismo y Comunidades Indígenas: Impactos, Pautas para Autoevaluación y Códigos de Conducta. 2016. Available online: http://www.ilo.org/wcmsp5/groups/public/@ed_emp/@emp_ent/@ifp_ seed/documents/publication/wcms_117521.pdf (accessed on 7 March 2020).

106. MINTUR. Ministerio de Turismo del Ecuador, 2007; PLANDETUR 2020; Ministerio de Turismo del Ecuador: Quito, Ecuador, 2007.

107. Bohórquez, J.V. Modelo de desarrollo de turismo comunitario del sector costero de la Provincia del Guayas (Primera Parte). Espirales Revista Multidisciplinaria Investigación 2017, 1, 14-30. [CrossRef]

108. Yuctor, M.E. Analysis of the Community Tourism Offer in the Province of Azuay/Análisis de la Oferta de Turismo Comunitario en la Provincia del Azuay; Universidad de Cuenca: Cuenca, Ecuador, 2011. 
109. MINTUR-Ministerio de Turismo del Ecuador. National Tourist Cadastre of Establishments/Catastro Turístico Nacional de Establecimientos; Ministerio de Turismo del Ecuador: Quito, Ecuador, 2020; Available online: https://servicios.turismo.gob.ec/index.php/turismo-cifras/2018-09-18-21-11-17/ establecimientos-registrados (accessed on 7 March 2020).

110. Ochoa, W. Basic Study Guide for Community and Solidarity Tourism/Guía básica de Estudio de Turismo Comunitario y Solidario; FEPTCE-Federacion Plurinacional de Turismo Comunitario del Ecuador: Quito, Ecuador, 2009.

111. FUNDECOL. 2020. Available online: http://www.ecuanex.net.ec/fundecol/ (accessed on 7 May 2020).

112. Cabanilla, E.; Socio-Spatial Configuration of Community Tourism, Republic of Ecuador Case/Configuración Socio-Espacial del Turismo Comunitario, Caso República del Ecuador. Universidad Nacional del Sur, Ecuador. 2016. Available online: https://www.researchgate.net/publication/317381708_Configuracion_socioespacial_del_turismo_comunitario_caso_Republica_del_Ecuador\%0D (accessed on 7 May 2020).

113. Barreto, D.; Design of a Tourist Circuit in the Muisne River Estuary Mangrove Wildlife Refuge, Muisne Canton, Esmeraldas Province/Diseño de un Circuito Turístico en el Refugio de Vida Silvestre Manglares Estuario del Río Muisne, Cantón Muisne, Provincia de Esmeraldas. Escuela Superior Politécnica de Chimborazo, Ecuador. 2016. Available online: http://dspace.espoch.edu.ec/bitstream/123456789/4703/1/23T0502.pdf (accessed on 7 May 2020).

114. Tourism Muisne/Muisne Turismo. Turismo Comunitario en Muisne. 2020. Available online: http: //www.muisneturismo.com/index.php/construction/turismo-comunitario (accessed on 7 May 2020).

115. Pescador, M. Centro Martín Pescador. Available online: https://1880-ec.all.biz/goods (accessed on 7 May 2020).

116. Cárdenas, C.; Chachalo, A. Sistematización de la Experiencia "Runa Tupari Native Travel-Encuentro con Indígenas; Centro Ecuatoriano de Derecho Ambiental: Quito, Ecuador, 2009.

117. Vizcaino, I.; The Political Participation of Indigenous Women within Community Organizations from the Perspective of Human Development. The case of the Union of Peasant and Indigenous Organizations of Cotacachi (UNORCAC), Ecuador (2009-2014)/La Participación Política de las Mujeres Indígenas al Interior de las Organizaciones Comunitarias Desde la Perspectiva de Desarrollo Humano. El caso de la Unión de Organizaciones Campesinas e Indígenas de Cotacachi (UNORCAC), Ecuador (2009-2014). 2009. Available online: https://repositorio.flacsoandes.edu.ec/bitstream/10469/15642/2/TFLACSO-2019IAVI.pdf (accessed on 7 May 2020).

118. Salas, A. Rune Tupari: Between community tourism and utopia/Runa Tupari: Entre el turismo comunitario y la utopía. Kalpana 2012, 7, 19-27.

119. Runa Tupari. Our company/Nuestra Empresa. Operadora de Turismo Comunitario. 2019. Available online: https://www.runatupari.com/index.php/home/nuestra-empresa.html (accessed on 10 March 2020).

120. Runa Tupari. Knowledge Route/Ruta del Conocimiento. 2014. Available online: https://ruta.runatupari.com/ index.php/paquete-turistico-1 (accessed on 10 March 2020).

121. CORDTUCH. Chimborazo from Inside/Chimborazo desde Adentro; Corporación para el Desarrollo de Turismo Comunitario de Chimborazo: Chimborazo, Ecuador, 2019.

122. CORDTUCH. Community Tourism in Ecuador 2018/Turismo Comunitario en el Ecuador. 2018. Available online: https://www.cordtuch.org/acerca-de-2 (accessed on 7 May 2020).

123. CORDTUCH. Chimborazo Community Tourism/Chimborazo Turismo Comunitario. December 2019. Available online: https://issuu.com/cordtuch.org/docs/revista_chimborazo_desde_adentro2_05d78b620ee5b8 (accessed on 7 May 2020).

124. Sagba, N.M. Analysis of the Current Situation of Community Tourism Linked to the Heritage Train Route and Subtropical Route in the Province of Chimborazo/Análisis de la Situación Actual del Turismo Comunitario Vinculado a la Ruta del Tren Patrimonial y Ruta Subtropical en la Provincia de Chimborazo; Escuela Superior Politécnica de Chimborazo: Chimborazo, Ecuador, 2017.

125. Diario La Nación. Pakariñan Tours Dominate the Country's South/Tours de Pakariñan Dominan el Austro del País. 2018. Available online: https://lanacion.com.ec/tours-de-pakarinan-dominan-el-austro-del-pais/ (accessed on 12 March 2020).

126. Sarmiento, C. Propuesta de Innovación de la Cocina Índigena del Pueblo Cañari Asociada a la Red de Turismo Comunitario Sumak Pacha. Universidad de Cuenca: Cuenca, Ecuador, 2012. Available online: http://dspace.ucuenca.edu.ec/handle/123456789/1568 (accessed on 12 May 2020). 
127. Pakariñan. Pakariñan-Early 2016/Pakariñan-Principios de 2016; Pakariñan-Red de Turismo Comunitario: Cuenca, Ecuador, 2016; Available online: https://issuu.com/pakarinan/docs/brochure_pakarin_an_2016 (accessed on 12 March 2020).

128. Arévalo, C.; Romero, R. Community Tourism in Azuay and Cañar: A Situational Review/Turismo Comunitario en Azuay y Cañar: Una Revisión Situacional; Universidad del Azuay: Azuay, Ecuador, 2018; Available online: http://dspace.uazuay.edu.ec/bitstream/datos/7972/1/13710.pdf (accessed on 25 March 2020).

129. La Revista. The Southern Pakariñán Routes/Las Sureñas Rutas de Pakarinán. 2016. Available online: http://www.larevista.ec/viajes/viajemos/las-surenas-rutas-de-pakarinan (accessed on 25 March 2020).

130. Encalada, E. Nature, Gastronomy and Adventure in Zamora Chinchipe/Naturaleza, Gastronomía y Aventura en Zamora Chinchipe; Diario El Comercio: Lima, Peru, 2019; Available online: https://www.elcomercio.com/ tendencias/naturaleza-gastronomia-aventura-zamora-chinchipe.html (accessed on 12 March 2020).

131. TourCert. Community Sisid Anejo/Comunidad Sisid Anejo. 2019. Available online: https://www.tourcert. org/es/community/sisid-anejo/ (accessed on 12 March 2020).

132. Kushi Waira Cultural Center. Kushi Waira Tour Program. 2008. Available online: http://www.kushiwaira. com/daytours.html (accessed on 7 May 2020).

133. Discover Ecuador. Community Tourism Network of the Cañari Sumak Pacha People/Red de Turismo Comunitario del Pueblo Cañari Sumak Pacha. 2018. Available online: https://discoverecuadorandmore.com/ecuador/regionsof-ecuador/sierra-regiones-de-ecuador/red-de-turismo-comunitario-del-pueblo-canari-sumak-pacha.html (accessed on 9 March 2020).

134. Pomavilla, N. Proposal for Tourist Signage for the La Carbonería Community Tourism Center, in the Cañar Canton/Propuesta de Señalética Turística para el Centro de Turismo Comunitario La Carbonería, del Cantón Cañar; Universidad de Cuencea: Cuencea, Ecuador, 2016; Available online: http://dspace.ucuenca.edu.ec/handle/ 123456789/23579 (accessed on 9 March 2020).

135. Diario El Comercio. 3 Cantons of Cañar Unite by Works/3 Cantones de Cañar se Unen por Obras. 2010. Available online: https://www.elcomercio.com/actualidad/ecuador/cantones-canar-unen-obras.html (accessed on 7 April 2020).

136. Quintero, D. Culinary Training in Handling, Serving, Preparing, and Costing Food and Beverages for the Community Tourism Network of the Cañari Sumak Pacha People in the Cañar Canton/Capacitación Culinaria en Manipulación, Servicio, Preparación, y Costeo de Alimentos y Bebidas, para la Red de Turismo Comunitario del Pueblo Cañari Sumak Pacha del Cantón Cañar; Universidad de Cuenca: Cuenca, Ecuador, 2012; Available online: http: //dspace.ucuenca.edu.ec/handle/123456789/1590 (accessed on 7 April 2020).

137. Turismo Cañar. Sisid Anejo Community Tourism Center/Centro de Turismo Comunitario Sisid Anejo. 2020. Available online: http://turismocanar.gob.ec/index.php/pages/ecoturismomnu-4/179-centro-de-turismocomunitario-sisid (accessed on 7 April 2020).

138. Saraurku. Community Tourism Network/Red de Turismo Comunitario. 2020. Available online: https: //www.saraurku.com/red-saraguro-rikuy/ (accessed on 7 April 2020).

139. GAD Municipal Intercultural of Saraguro. Saraguro Tourism Guide/Guía de Turismo Saraguro. 2020. Available online: https://drive.google.com/file/d/1PPPVK9Chaq7mzVynAMC1BgqVbyiAPaj-/view (accessed on 7 May 2020).

140. Falconí, F.; Ponce, J. Social and Economic Development of the Ecuadorian Amazon Based on Ecotourism: Popular Ventures as an Alternative to Exclusive Development/Desarrollo Social y Económico de la Amazonía Ecuatoriana Basado en el Ecoturismo: Emprendimientos Populares Como Alternativa a un Desarrollo Excluyente; Fundació Càtedra Iberoamericana: Madrid, Spain, 2004; Available online: https:/fci.uib.es/Servicios/libros/investigacion/ falconi/El-proyecto-RICANCIE.cid216609 (accessed on 7 May 2020).

141. RICANCIE. RICANCIE.We/RICANCIE. Nosotros. 2019. Available online: http://ricancie.nativeweb.org/es/ nosotros2 (accessed on 7 May 2020).

142. Infonapo. Community Tourism/Turismo Comunitario. 2018. Available online: http://info.napo.gob.ec/ turismo_comunitario.html (accessed on 7 May 2020).

143. Fund for the Achievement of the Millennium Development Goals. Community Tourism/Turismo Comunitario. 2020. Available online: http://www.mdgfund.org/es/node/3319 (accessed on 7 April 2020). 
144. Italo-Ecuadorian Fund for Sustainable Development. Community Tourism, Crafts and Productive Agricultural Diversification, Indigenous Communities of Sucumbíos/Turismo Comunitario, Artesanía y Diversificación Agrícola Productiva, Comunidades Indígenas de Sucumbíos. 2017. Available online: https:/fieds.org/historia-fie/convocatoria/turismo-comunitario-artesania-y-diversificacion-agricola-productivacomunidades-indigenas-de-sucumbios/ (accessed on 7 April 2020).

145. Montesdeoca, S. Sustainable Tourism Development Plan for Communities Affiliated to CORTUS/Plan de Desarrollo Turístico Sostenible para las Comunidades Afiliadas a la CORTUS; Escuela Superior Politécnica de Chimborazo: Chimborazo, Ecuador, 2014; Available online: http://dspace.espoch.edu.ec/bitstream/123456789/3452/1/ 23T0403.pdf (accessed on 7 April 2020).

146. Newspaper El Universo. Community Tourism in Sucumbíos/Turismo Comunitario en Sucumbíos. La Revista. 2016. Available online: http:/www.larevista.ec/viajes/viajemos/turismo-comunitario-en-sucumbios?fbclid= IwAR3sRmLt9AniVq7t4Uu4mstRz9wzGaGcMTVGpxQoDeAExXKT7IDqqiSBLf0 (accessed on 7 May 2020).

147. CTC Shayari. 2019. Available online: https://www.facebook.com/pg/ctcshayari/about/?ref=page_internal (accessed on 7 May 2020).

148. La Geoguía Project. Siecoya Remolino Community Tourism Center/ECUADOR/Centro de Turismo Comunitario Siecoya Remolino/ECUADOR. Available online: http://www.lageoguia.org/centro-de-turismocomunitario-siecoya-remolino-ecuador/\#14/-0.2962/-76.3085 (accessed on 7 May 2020).

149. Reyes, M.V.; Ortega, Á.F. Community Tourism, Reality in Pastaza/Turismo Comunitario, Realidad en Pastaza; Universidad Estatal Amazónica: Puyo, Ecuador, 2013.

150. PROCASUR. The Experience of the Network of Community Tourist Centers of the Arajuno Canton/La experiencia de la Red de Centros Turísticos Comunitarios del Cantón Arajuno. 2013. Available online: http://juventudruralemprendedora.procasur.org/wp-content/uploads/2014/05/ Sistematización-Canton-Arajuno-Final.pdf (accessed on 16 March 2020).

151. GAD Municipal Intercultural y Plurinacional Arajuno Cantón. Tourims 2012/Turismo 2012. Available online: https://www.arajuno.gob.ec/arajuno/index.php/turismo (accessed on 19 March 2020).

152. Yánez, G. Evaluation of the Rural Tourism Potential of the Arajuno Canton, Pastaza Province, for the Design of a Tourist Product/Evaluación del Potencial de Turismo Rural del Cantón Arajuno, Provincia de Pastaza, para el Diseño de un Producto Turístico; Universidad Estatal Amazónica: Puyo, Ecuador, 2013; Available online: https://repositorio.uea.edu.ec/xmlui/bitstream/handle/123456789/208/T.TUR.B.UEA.4047? sequence $=1 \&$ isAllowed $=y$ (accessed on 19 March 2020).

153. Pastaza Travel. Community Tourism/Turismo Comunitario. 2019. Available online: https://pastaza.travel/ que-hacer/turismo-comunitario/ (accessed on 19 March 2020). 